\title{
Energy and Water Conservation Assessment of the Radiochemical Processing Laboratory (RPL) at Pacific Northwest National Laboratory
}

SR Johnson

TM Koehler

BK Boyd

May 2014

Pacific Northwest

NATIONAL LABORATORY

Proudly Operated by Battelle Since 1965 


\title{
DISCLAIMER
}

This report was prepared as an account of work sponsored by an agency of the United States Government. Neither the United States Government nor any agency thereof, nor Battelle Memorial Institute, nor any of their employees, makes any warranty, express or implied, or assumes any legal liability or responsibility for the accuracy, completeness, or usefulness of any information, apparatus, product, or process disclosed, or represents that its use would not infringe privately owned rights. Reference herein to any specific commercial product, process, or service by trade name, trademark, manufacturer, or otherwise does not necessarily constitute or imply its endorsement, recommendation, or favoring by the United States Government or any agency thereof, or Battelle Memorial Institute. The views and opinions of authors expressed herein do not necessarily state or reflect those of the United States Government or any agency thereof.

\author{
PACIFIC NORTHWEST NATIONAL LABORATORY \\ operated by \\ BATTELLE \\ for the \\ UNITED STATES DEPARTMENT OF ENERGY \\ under Contract DE-AC05-76RL01830 \\ Printed in the United States of America \\ Available to DOE and DOE contractors from the \\ Office of Scientific and Technical Information, \\ P.O. Box 62, Oak Ridge, TN 37831-0062; \\ ph: (865) 576-8401 \\ fax: $(865) 576-5728$ \\ email: reports $@$ adonis.osti.gov \\ Available to the public from the National Technical Information Service \\ 5301 Shawnee Rd., Alexandria, VA 22312 \\ ph: (800) 553-NTIS (6847) \\ email: ordersantis,gov <http://www.ntis.gov/about/form.aspx> \\ Online ordering: http://www.ntis.gov
}




\section{Energy and Water Conservation Assessment of the Radiochemical Processing Laboratory (RPL) at Pacific Northwest National Laboratory}

SR Johnson

TM Koehler

BK Boyd

May 2014

Prepared for

the U. S. Department of Energy

under Contract DE-AC05-76RL01830

Pacific Northwest National Laboratory

Richland, Washington99352 



\section{EISA Assessment Summary}

This report summarizes the results of an energy and water conservation assessment of the Radiochemical Processing Laboratory (RPL) at Pacific Northwest National Laboratory (PNNL). The assessment was performed in October 2013 by engineers from the PNNL Building Performance Team with the support of the dedicated RPL staff and several Facilities and Operations (F\&O) department engineers. The assessment was completed for the Facilities and Operations (F\&O) department at PNNL in support of the requirements within Section 432 of the Energy Independence and Security Act (EISA) of 2007. EISA requires comprehensive energy and water evaluations on the top $75 \%$ of a site's total covered facility energy use. EISA requires an assessment similar to a Level 1 American Society of Heating, Refrigerating and Air-Conditioning Engineers (ASHRAE) energy audit, which consists of an initial building walkthrough and identification of energy and water conservation measures (ECMs and WCMs). This report covers these requirements. A Level 1 energy audit also requires re/retro commissioning opportunity identification, which F\&O is covering in a separate effort.

The model simulation and engineering analysis did not return many large life cycle cost effective capital improvements, which was expected because the Radiochemical Process Laboratory (RPL) is a Hazard Category-II Nuclear Facility with a unique nuclear science and technology mission that requires following specific operational and maintenance (O\&M) guidelines. The mandatory O\&M guidelines that require running RPL ventilation equipment continuously, irrespective of the day of the week or holidays, eliminate the typical building ECMs that can be deployed. In addition, the energy unit costs are relatively low for the area and craft labor costs are high which results in undesirable paybacks. Additionally, to carry out the facility's mission, the 1953 building has been renovated over the years. Approximately \$50M has been invested in facility life extension and upgrades; now housing more than 87 laboratories, 16 hot cells, 160 fume hoods and 25 glove boxes for work with radioactive materials. In FY13, RPL was designated by DOE as a High Performance Sustainable Building (HPSB), the first DOE Office of Science nuclear laboratory to achieve such status. HPSB designation is based on five guiding principles for existing buildings: integrated design, optimized energy use, water conservation, enhanced indoor environmental quality, and reduced environmental impact of materials.

Table 1 and Table 2 summarize the results of the assessment by ECM or WCM category. The retrofit candidates include building envelope; lighting; heating, ventilation and air conditioning (HVAC); other; and water. The detailed results for each ECM and WCM type can be found in the main body of this report. Table 1 lists those ECMs that are economically feasible and considered a high priority to RPL, while Table 2 are those ECMs and WCMs that are either not cost-effective or are not considered a high priority for RPL. Some of these "best practice" measures were included despite the fact that the high labor costs ranked them economically less desirable; these ECMs/WCMs should be considered when the equipment and/or system requires replacement.

If F\&O implemented all the cost-effective energy- and cost-reducing projects identified in Table 1, they could save 16,058 MMBtu and \$131,921 per year. This represents a 48\% reduction of energy use at RPL based on energy consumption during September 2012 - August 2013 with a simple payback period of 4.9 years. However, prior to embarking on a retrofit campaign, it is recommended that additional comprehensive evaluations (i. e. capital cost and savings assessments) be completed for all these projects due to the unique hazards (radiological, asbestos, and beryllium) associated with the facility. 
Table 1. Summary of Suggested ECMs

\begin{tabular}{|c|c|c|c|c|c|c|c|}
\hline Measure & $\begin{array}{c}\text { Total Energy } \\
\text { Savings } \\
\text { (MMBtu/yr) } \\
\end{array}$ & $\begin{array}{c}\text { Total Water } \\
\text { Savings } \\
\text { (Kgal/yr) } \\
\end{array}$ & $\begin{array}{c}\text { Annual } \\
\text { Energy Cost } \\
\text { Savings (\$/yr) } \\
\end{array}$ & $\begin{array}{c}\text { Annual } \\
\text { O\&M } \\
\text { Savings } \\
\text { (\$/yr) } \\
\end{array}$ & $\begin{array}{c}\text { Total } \\
\text { Annual } \\
\text { Savings } \\
(\$ / y r) \\
\end{array}$ & $\begin{array}{c}\text { Capital } \\
\text { Costs } \\
\end{array}$ & $\begin{array}{c}\text { Simple } \\
\text { Payback } \\
\text { (yr) } \\
\end{array}$ \\
\hline \multicolumn{8}{|c|}{ Building Envelope } \\
\hline $\begin{array}{c}\text { Install Second Floor } \\
\text { Vestibule }\end{array}$ & 210 & 0 & $\$ 1,919$ & $\$ 0$ & $\$ 1,919$ & $\$ 22,968$ & 12. 0 \\
\hline \multicolumn{8}{|c|}{ Lighting } \\
\hline Replace Exit Signs & 1 & 0 & $\$ 8$ & $\$ 743$ & $\$ 751$ & $\$ 8,064$ & 10.7 \\
\hline $\begin{array}{c}\text { Replace HLRF } \\
\text { Lighting }\end{array}$ & 4 & 0 & $\$ 89$ & $\$ 398$ & $\$ 487$ & $\$ 8,083$ & 16. 5 \\
\hline \multicolumn{8}{|c|}{ HVAC } \\
\hline $\begin{array}{c}\text { Convert High } \\
\text { Pressure Steam } \\
\text { System to Hot } \\
\text { Water }\end{array}$ & 7,109 & 0 & $\$ 57,418$ & $\$-4,351$ & $\$ 53,067$ & $\$ 524,680$ & 9.9 \\
\hline $\begin{array}{c}\text { Apply Temperature } \\
\text { Setback }\end{array}$ & 3,544 & 0 & $\$ 25,103$ & $\$ 0$ & $\$ 25,103$ & $\$ 200$ & 0.0 \\
\hline $\begin{array}{l}\text { Install VFDs on } \\
\text { Supply and Exhaust } \\
\text { Fans }\end{array}$ & 5,190 & 0 & $\$ 50,594$ & $\$ 0$ & $\$ 50,594$ & $\$ 79,994$ & 1. $6^{2}$ \\
\hline Total & 16,058 & 0 & $\$ 135,131$ & $\$-3,210$ & $\$ 131,921$ & $\$ 643,989$ & 4.9 \\
\hline
\end{tabular}

If F\&O implemented all the energy and water cost-reducing projects identified in Table 2, they could save an additional 2,298 MMBtu, 155 thousand gallons of water, and \$35,624 per year. This represents a $7 \%$ reduction of energy and $31 \%$ water use at RPL.

\footnotetext{
${ }^{1}$ High level assessment based on converting a central steam plant to a decentralized hot water system

2 The energy savings was determined by the FEDS model based on adding variable frequency drives (VFD)s to the existing supply and exhaust fans; however, this ECM is superseded by another more detailed analysis which recommended new fans and VFDs with harmonic filters. This approach took into account RPL's long term mission ensuring a life expectancy of $30+$ years for the exhaust system while mitigating any harmonic disturbances.
} 
Table 2. Additional ECMs and WCMs for Consideration

\begin{tabular}{|c|c|c|c|c|c|c|c|c|}
\hline Measure & $\begin{array}{c}\text { Total Energy } \\
\text { Savings } \\
\text { (MMBtu/yr) }\end{array}$ & $\begin{array}{c}\text { Total Water } \\
\text { Savings } \\
\text { (Kgal/yr) }\end{array}$ & $\begin{array}{c}\text { Annual Energy } \\
\text { Cost Savings } \\
(\$ / y r) \\
\end{array}$ & $\begin{array}{c}\text { Annual } \\
\text { Water } \\
\text { Cost } \\
\text { Savings } \\
\text { (\$/yr) }\end{array}$ & $\begin{array}{c}\text { Annual } \\
\text { O\&M } \\
\text { Savings } \\
\text { (\$/yr) }\end{array}$ & $\begin{array}{c}\text { Total } \\
\text { Annual } \\
\text { Savings } \\
\text { (\$/yr) } \\
\end{array}$ & $\begin{array}{c}\text { Capital } \\
\text { Costs }\end{array}$ & $\begin{array}{c}\text { Simple } \\
\text { Payback } \\
\text { (yr) }\end{array}$ \\
\hline \multicolumn{9}{|c|}{ Building Envelope } \\
\hline $\begin{array}{l}\text { Upgrade South } \\
\text { Windows }\end{array}$ & 50 & 0 & $\$ 403$ & $\$ 0$ & $\$ 0$ & $\$ 403$ & $\$ 27,234$ & 67.6 \\
\hline $\begin{array}{l}\text { Upgrade Roof } \\
\text { Insulation }\end{array}$ & 957 & 0 & $\$ 9,555$ & $\$ 0$ & $\$ 0$ & $\$ 9,555$ & $\$ 293,619$ & 30.7 \\
\hline \multicolumn{9}{|c|}{ Lighting } \\
\hline $\begin{array}{l}\text { Lighting } \\
\text { Occupancy } \\
\text { Sensors } \\
\end{array}$ & 716 & 0 & $\$ 18,057$ & $\$ 0$ & $\$ 0$ & $\$ 18,057$ & $\$ 162,180$ & 9. 0 \\
\hline $\begin{array}{c}\text { Replace T12 } \\
\text { Lighting }\end{array}$ & 2. 5 & 0 & $\$ 23$ & $\$ 0$ & $\$ 65$ & $\$ 88$ & $\$ 7,308$ & 83. 0 \\
\hline \multicolumn{9}{|c|}{ HVAC } \\
\hline $\begin{array}{c}\text { HVAC Small } \\
\text { Motor } \\
\text { Upgrades } \\
\end{array}$ & 505 & 0 & $\$ 6,097$ & $\$ 0$ & $\$ 0$ & $\$ 6,097$ & $\$ 302,508$ & 49. 6 \\
\hline \multicolumn{9}{|c|}{ Other } \\
\hline $\begin{array}{c}\text { Smart Power } \\
\text { Strips }\end{array}$ & 52 & 0 & $\$ 472$ & $\$ 0$ & $\$ 0$ & $\$ 472$ & $\$ 21,143$ & 44.8 \\
\hline \multicolumn{9}{|c|}{ Water } \\
\hline $\begin{array}{c}\text { Toilet } \\
\text { Replacement }\end{array}$ & 0 & 81 & $\$ 0$ & $\$ 346$ & $\$ 0$ & $\$ 346$ & $\$ 7,431$ & 21.5 \\
\hline $\begin{array}{c}\text { Urinal } \\
\text { Replacement }\end{array}$ & 0 & 21 & $\$ 0$ & $\$ 90$ & $\$ 0$ & $\$ 90$ & $\$ 4,527$ & 50.1 \\
\hline $\begin{array}{c}\text { Faucet } \\
\text { Replacement }\end{array}$ & 14 & 42 & $\$ 219$ & $\$ 179$ & $\$ 0$ & $\$ 398$ & $\$ 188$ & 0.5 \\
\hline $\begin{array}{l}\text { Showerhead } \\
\text { Replacement }\end{array}$ & 4 & 11 & $\$ 70$ & $\$ 48$ & $\$ 0$ & $\$ 118$ & $\$ 167$ & 1. 4 \\
\hline Total & 2,298 & 155 & $\$ 34,896$ & $\$ 663$ & $\$ 65$ & $\$ 35,624$ & $\$ 826,305$ & 23.2 \\
\hline
\end{tabular}


Table 3 displays the totals from Table 1 and Table 2.

Table 3. Totals from all Measures Evaluated

\begin{tabular}{|c|c|c|c|c|c|c|c|c|}
\hline Measure & $\begin{array}{c}\text { Total } \\
\text { Energy } \\
\text { Savings } \\
\text { (MMBtu/yr) }\end{array}$ & $\begin{array}{c}\text { Total } \\
\text { Water } \\
\text { Savings } \\
\text { (Kgal/yr) }\end{array}$ & $\begin{array}{c}\text { Annual } \\
\text { Energy } \\
\text { Cost } \\
\text { Savings } \\
(\$ / y r) \\
\end{array}$ & $\begin{array}{c}\text { Annual } \\
\text { Water Cost } \\
\text { Savings } \\
\text { (\$/yr) }\end{array}$ & $\begin{array}{l}\text { Annual } \\
\text { O\&M } \\
\text { Savings } \\
\text { (\$/yr) }\end{array}$ & $\begin{array}{c}\text { Total } \\
\text { Annual } \\
\text { Savings } \\
\text { (\$/yr) } \\
\end{array}$ & $\begin{array}{l}\text { Capital } \\
\text { Costs }\end{array}$ & $\begin{array}{c}\text { Simple } \\
\text { Payback } \\
\text { (yr) }\end{array}$ \\
\hline $\begin{array}{l}\text { Recommended } \\
\text { Measures }\end{array}$ & 16,058 & 0 & $\$ 135,131$ & $\$ 0$ & $\$-3,210$ & $\$ 131,921$ & $\$ 643,989$ & 4. 9 \\
\hline $\begin{array}{l}\text { Measures for } \\
\text { Consideration }\end{array}$ & 2,298 & 155 & $\$ 34,896$ & $\$ 663$ & $\$ 65$ & $\$ 35,624$ & $\$ 826,305$ & 23. 2 \\
\hline Total & 18,356 & 155 & $\$ 170,027$ & $\$ 663$ & \$-3,145 & $\$ 167,545$ & $\$ 1,470,294$ & 8. 8 \\
\hline
\end{tabular}




\section{Acronyms and Abbreviations}

\begin{tabular}{|c|c|}
\hline ASHRAE & American Society of Heating, Refrigerating and Air-Conditioning Engineers \\
\hline BAS & building automation system \\
\hline BOCC & Building Operation Control Center \\
\hline BPA & Bonneville Power Administration \\
\hline CFL & compact fluorescent lamp \\
\hline CRREL & Cold Regions Research and Engineering Laboratory \\
\hline CUP & central utilities plant \\
\hline CY & calendar year \\
\hline DSOM & Decision Support for Operations and Maintenance \\
\hline ECAM & Energy Charting and Metrics Tool \\
\hline ECM & energy conservation measure \\
\hline EISA & Energy Independence and Security Act \\
\hline ESPC & energy savings performance contract \\
\hline EUI & energy use intensity \\
\hline $\mathrm{F} \& \mathrm{O}$ & Facilities and Operations \\
\hline FEDS & Facility Energy Decision System \\
\hline gpf & gallons per flush \\
\hline gpm & gallons per minute \\
\hline GSA & U. S. General Services Administration \\
\hline HLRF & High Level Radiochemistry Facility \\
\hline hp & horse power \\
\hline HPS & high-pressure sodium \\
\hline HVAC & heating, ventilation and air conditioning \\
\hline JCI & Johnson Controls Inc. \\
\hline Kgal & thousand gallons \\
\hline kWh & kilowatt-hours \\
\hline LCC & life-cycle cost \\
\hline LED & light-emitting diode \\
\hline LEED & Leadership in Energy and Environmental Design \\
\hline LTHW & low temperature hot water \\
\hline Mgal & million gallons \\
\hline MMBtu & million British thermal units \\
\hline MSA & Mission Support Alliance \\
\hline NG & natural gas \\
\hline NPV & net present value \\
\hline $\mathrm{O} \& \mathrm{M}$ & operation and maintenance \\
\hline
\end{tabular}


PNNL

RPL

$\mathrm{SIOH}$

SIR

VAV

VFD

WCH

WCM

WUI
Pacific Northwest National Laboratory

Radiochemical Process Laboratory

supervision, inspection, and overhead

savings-to-investment ratio

variable-air volume

variable-frequency drive

Washington Closure Hanford

water conservation measure

water use intensity 


\section{Contents}

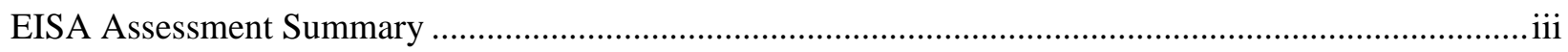

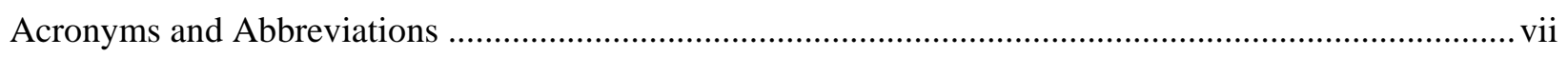

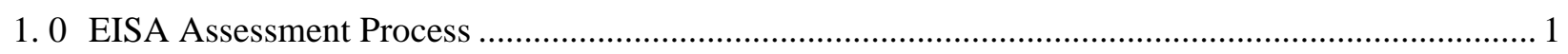

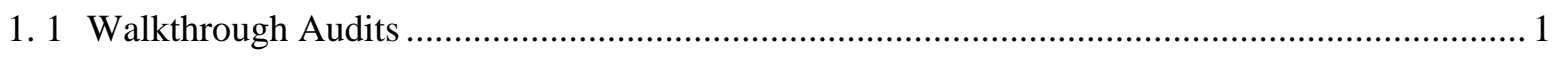

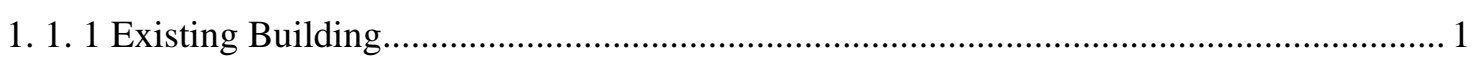

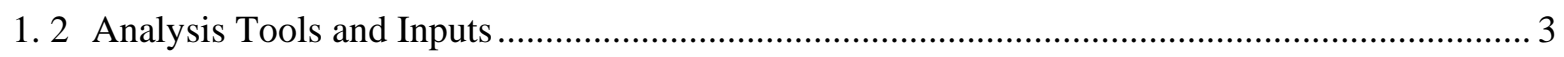

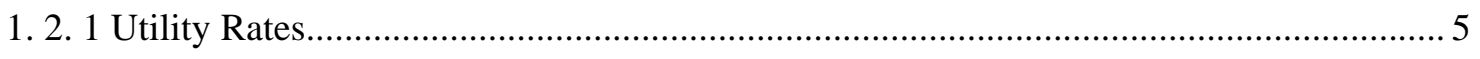

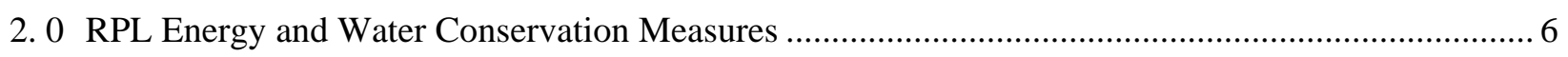

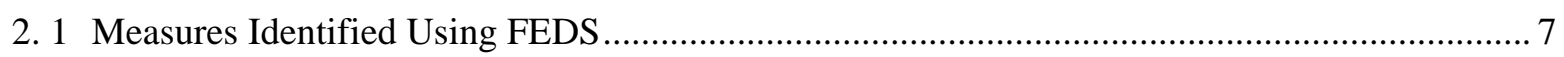

2. 1. 1 Replace Exit Signs with Electroluminescent Exit Signs ............................................... 7

2. 1. 2 Replace Metal Halide Lighting in HLRF .................................................................. 7

2. 2 Measures Identified Outside of FEDS.............................................................................. 7

2. 2. 1 Add a Second Floor Vestibule for Office Area ........................................................... 7

2. 2. 2 Convert steam system to hot water........................................................................... 9

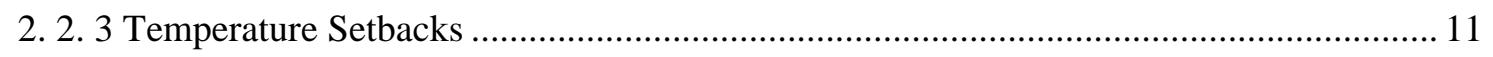

2. 2. 4 Add Variable-Frequency Drives (VFDs) for Supply and Exhaust Fans ......................... 12

2. 3 Additional ECMs and WCMs for Consideration ................................................................ 13

2. 3. 1 Install Commercial Style, High Performance Aluminum Frame Double Pane Argon/Low-Gain Windows..................................................................................... 14

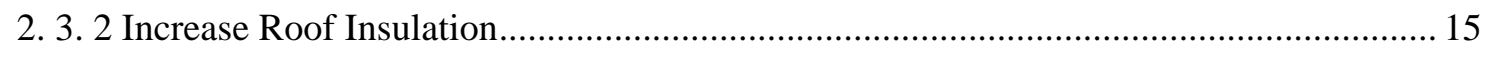

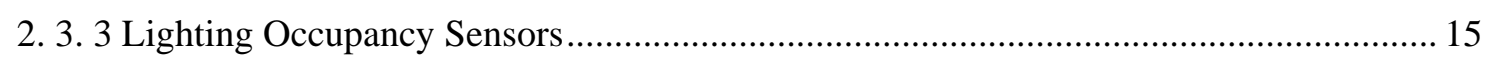

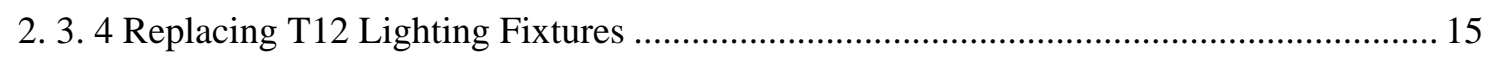

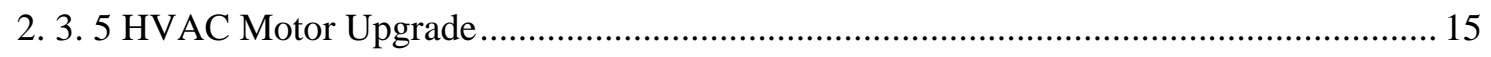

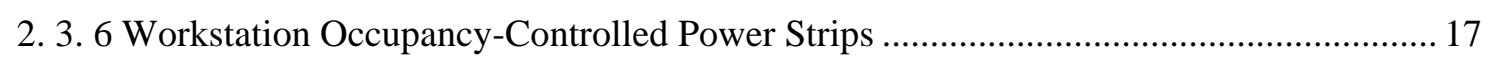

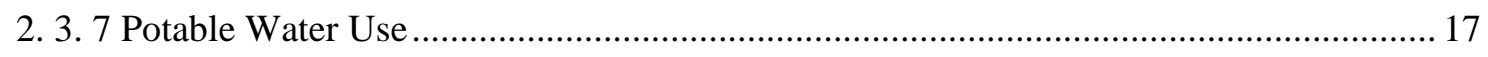

2. 4 Observations for Further Follow-Up .................................................................................... 22

2. 4. 1 Non-Administrative Plug Load Reduction ................................................................. 23

2. 4. 2 Add Variable Frequency Drives (VFDs) for Smaller Pumps/Motors ............................. 23

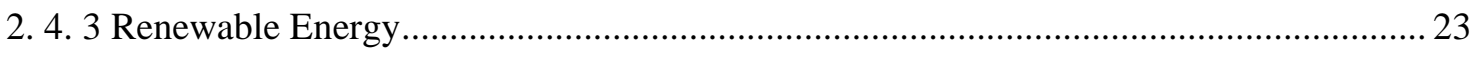

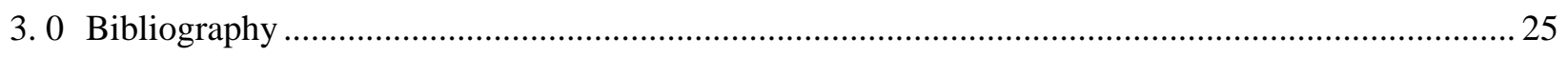

Appendix A Hourly Profile Analysis ............................................................................................ A.1

Appendix B FEDS Modeling, Calibration, and Outputs.......................................................................1

Appendix C Audit Forms Used During Walkthroughs............................................................................ 1

Appendix D Domestic Fixture Water Use Estimate ........................................................................ D.1

Appendix E Assumptions for Second Floor Vestibule ........................................................................... E.2

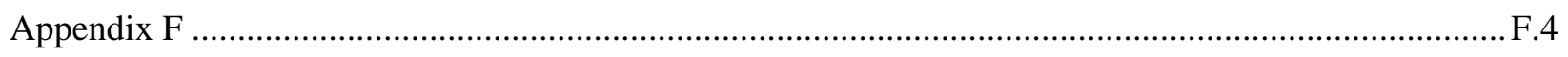

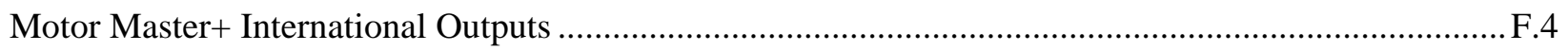




\section{Figures}

Figure 1. PNNL's Radiochemical Processing Laboratory .................................................................. 2

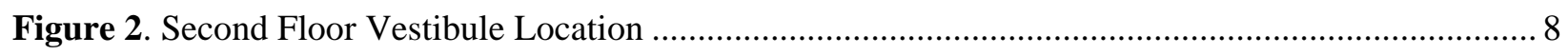

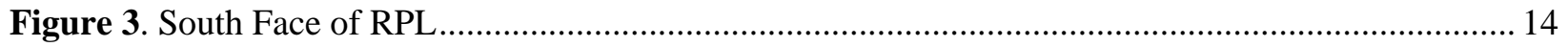

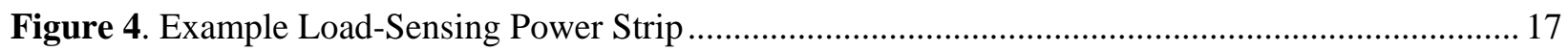

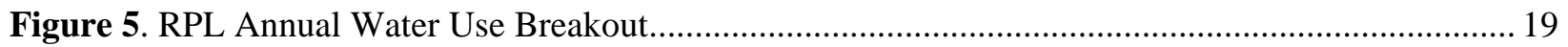

Figure 6. Efficient Locker Room Faucet............................................................................................. 20

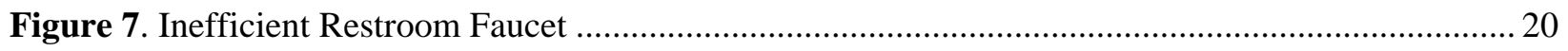

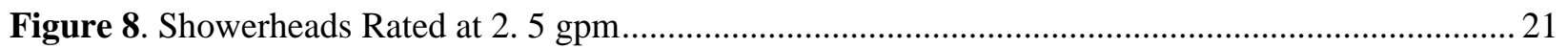

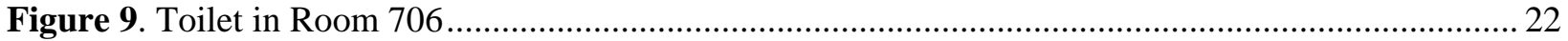




\section{Tables}

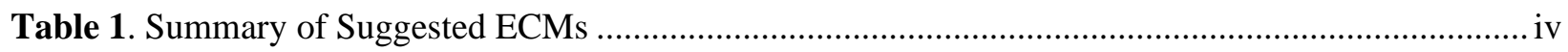

Table 2. Additional ECMs and WCMs for Consideration ..................................................................

Table 3. Totals from all Measures Evaluated...................................................................................... vi

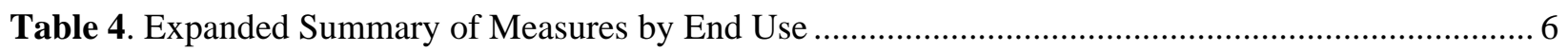

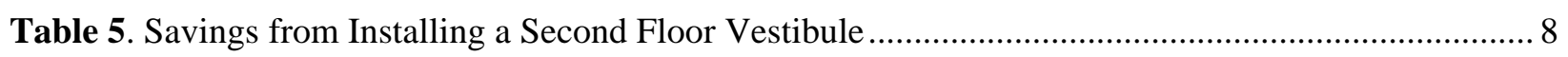

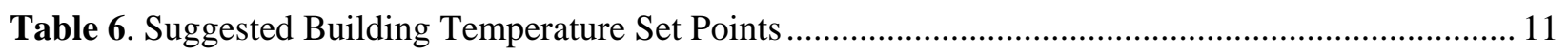

Table 7. Additional ECMs and WCMs for Consideration .................................................................... 13

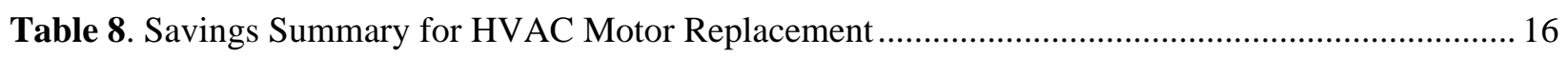

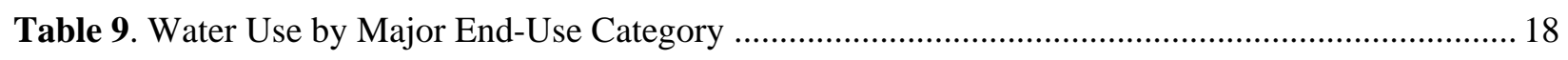

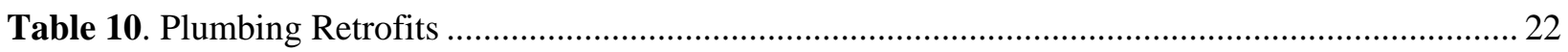





\subsection{EISA Assessment Process}

A combination of audits, modeling, and other analysis was used to assess the potential for energy and water conservation measures at the Radiochemical Processing Laboratory (RPL). In addition, the engineers from the Building Performance Team relied on and fully appreciated the efforts of the knowledgeable facilities staff such as Scott Colby, Tony Lechelt, John Logan, Marc Berman, Shan Belew, Steve Hultman, and former facility staff member Ron Underhill. In addition, RPL's dedicated staff was able to provide accurate key drawings, flow diagrams, system reports and provide up to date equipment condition.

\subsection{Walkthrough Audits}

The assessment team performed a walkthrough of RPL during the week of October 21, 2013, to conduct the building audit. During this visit, the assessment team collected energy and water information from the facility for input into the Facility Energy Decision System (FEDS) model (PNNL 2013) and other analysis tools. Additional information was gathered to estimate conditions in the laboratory areas of the facility that could not be accessed. The audit sheet used during the audit is shown in Appendix C.

In addition to the walkthrough, several other sources of information were gathered to assess the condition of the building. These information sources included as-built and modified drawings, specifications, and utility bills.

\subsubsection{Existing Building}

The Radiochemical Process Laboratory (RPL) is a Hazard Category-II Nuclear Facility operated by Pacific Northwest National Laboratory (PNNL). RPL celebrated its 60th anniversary in 2013. It was built in 1953 and known as Building 325, but was renamed the Radiochemical Processing Laboratory in 1996. RPL has been transformed into a cornerstone for the PNNL nuclear science and technology mission. Since 2006, approximately $\$ 50 \mathrm{M}$ has been invested in facility life extension and upgrades. The facility now houses more than 87 laboratories, 16 hot cells, 160 fume hoods and 25 glove boxes for work with radioactive materials. In FY13, RPL was designated by DOE as a High Performance Sustainable Building (HPSB), the first DOE Office of Science nuclear laboratory to achieve such status. HPSB designation is based on five guiding principles for existing buildings: integrated design, optimized energy use, water conservation, enhanced indoor environmental quality, and reduced environmental impact of materials.

RPL has a total square footage of 144,820and has a full basement and one above grade floor, both with office, laboratory, and mechanical space. A second floor mezzanine consists of offices and mechanical space. In addition, the building has an adjacent high-bay laboratory with a few offices. An approximate breakdown of the building is $31 \%$ laboratory space, $11 \%$ office space, and $58 \%$ common space (hallways, storage, and mechanical space). Figure $\mathbf{1}$ is an aerial view of the facility with the boiler annex, filter building, second floor, and high-bay lab spaces outlined in green. 


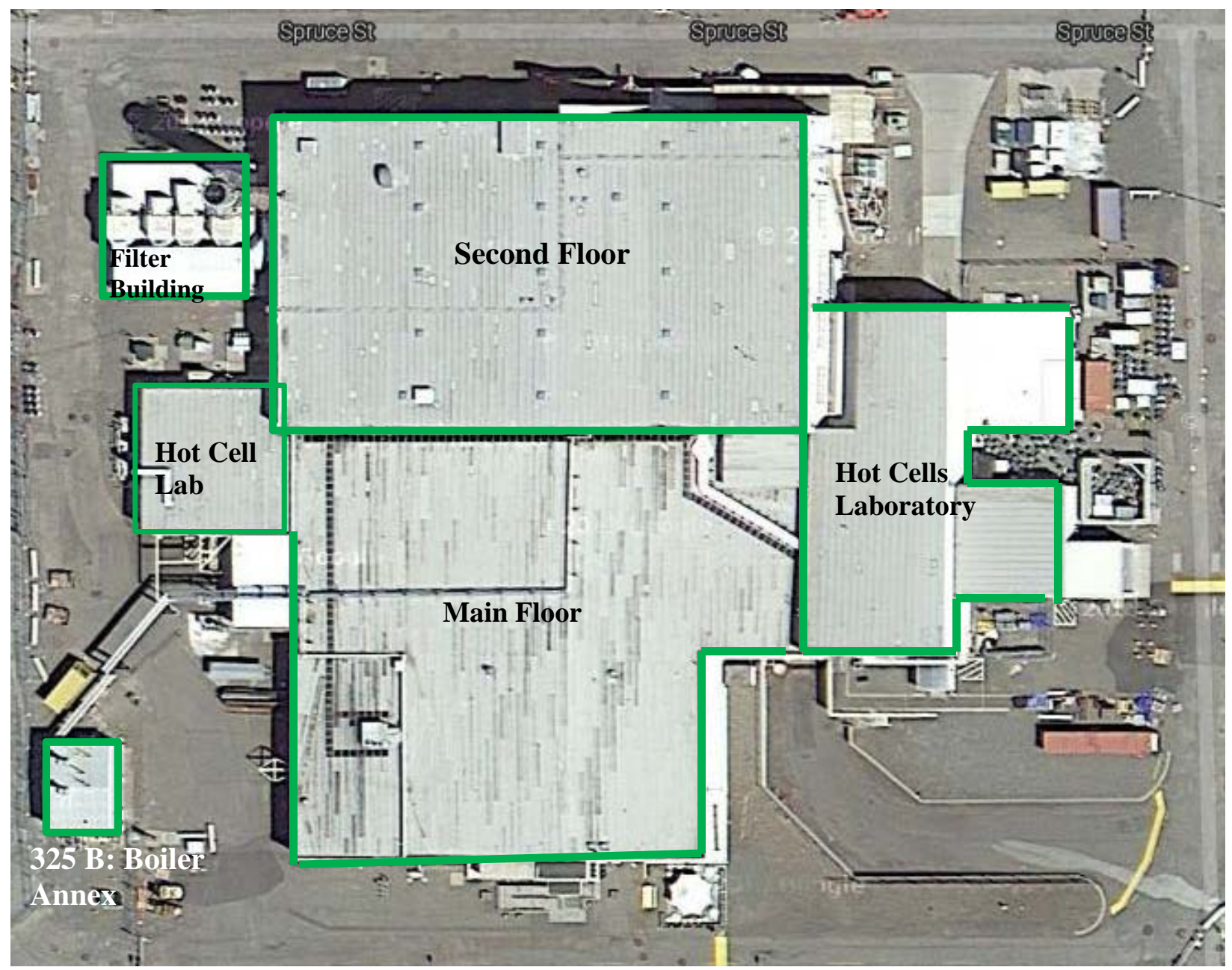

Figure 1. PNNL’s Radiochemical Processing Laboratory

There are four supply fans located on the second floor. The fans are ducted into a common building supply air plenum, and three of them deliver between 135,000 and 140,000 cfm, pulling 100\% outdoor air with one unit in standby. Each air handler is equipped with an outside air isolation damper, a hot water preheat coil, heat recovery coil, cooling coil, and a reheat coil. The fans are equipped with outside air isolation dampers and discharge air isolation dampers that are designed to close when the respective fan is off. The equipment is estimated to be original equipment installed in 1953, except the reheat coils that were installed in 1982. Unfortunately, according to a recent inspection ${ }^{3,}$ many of the old dampers are not completely sealing; thus causing conditioned air to leak out of the building.

The RPL exhaust system is composed of four belt driven fans that run at a constant speed of 1178 revolutions per minute (RPM). The exhaust fans also are equipped with vortex inlet dampers for flow control and have inlet and outlet dampers that close when the fan is off. During normal operations, three exhaust fans run continuously, and one is held in standby. Building exhaust passes through primary

\footnotetext{
${ }^{3}$ Ayers. W.S.. 2011.Engineering Study of Ventilation Supply and Exhaust Systems in the Radiochemical Process Laboratory.S663633-RPT-PM001, Revision 0. Pacific Northwest National Laboratory, Richland, WA. December 2011.
} 
HEPA filters located in close proximity to the rooms they serve and then passes through 4 Final HEPA banks located in the Filter Building. All four HEPA banks are normally on-line. Each bank is equipped with inlet and outlet isolation dampers to allow for taking the bank out of service for maintenance. The RPL exhaust system was modified in 1982. The modification involved the addition of heat recovery to the building, including the addition of heat recovery coils in the discharge air stream of each exhaust fan.

Building 325BA is a boiler annex building that is located outside of the RPL building. It houses two Cleaver Brooks packaged steam boilers (model \# CB-700-125-150). The boilers were installed as part of a 25year energy savings performance contract (ESPC) installed in 1997. The fire-tube boilers burn natural gas (NG) fuel and are designed to operate at a pressure of $150 \mathrm{psi}$ maximum. They are $125 \mathrm{hp}$, which indicates that they output $\sim 4313 \mathrm{lbs}$. $/ \mathrm{hr} .{ }^{4}$ of saturated steam, with a rated input of $\sim 5,103 \mathrm{kBtu} / \mathrm{hr}$ of NG. According to the boiler manufacturer, they have an average efficiency of $80 \%$ across the range of firing rates; however the nameplate efficiency is $82 \%$ and the boiler operator claimed $84 \%$, which was a conservative value used in the FEDS analysis. Based on the natural gas consumption in 2013 and confirmed by the boiler operator, one boiler is typically in standby mode, and the operation of the boilers are alternated. Although the consumption of fuel is weather dependent, the annex building also houses a Cleaver Brooks (45,000 gallon) water conditioner, a CB dearerator (8,000 lbs. /hr. capacity), a condensate tank, three feed water pumps and two condensate pumps. The operation of all the pumps is alternated; yet the pump run time hours indicate that some months the condensate pumps don't run at all or very little, indicating little to no condensate is being returned to the boiler.

Originally, the system was designed to provide high pressure and low pressure steam, but during the audit, the low pressure steam system was turned off, and building engineers stated that it may remain off for the cooling Season which ends October $31^{\text {st }}$. The primary user of the low pressure steam is the supply fan \#5 (SF-5). The high pressure steam is converted to hot water and primarily used for preheat and reheat coils for space heating. The operating pressure the day of the audit was $~ 100$ psig, but has since been dropped to approximately between 80 psig.

To cool the facility, two 300-ton chillers provide chilled water to the cooling coils in the main supply units. This system also provides cooling water for the second floor offices. Select spaces on the first floor have additional booster cooling coils that receive chilled water from the 300 ton units. In addition, there is a process chiller to provide cooling to the basement offices and select lab spaces and equipment, and an office chiller which provides cooling water for 4 fan coil units that serve first floor offices at the south end of the building. A small 10,350 cfm air handler, with 11 variable-air volume (VAV) units, is located on the second floor to supply the second floor ventilation, electric heating, and distribute the chilled water from the 300-ton central chillers.

\subsection{Analysis Tools and Inputs}

A FEDS model was developed for RPL and all fuels and equipment were accounted for. FEDS is a fuel-neutral, technology-independent software tool developed by PNNL that provides a comprehensive method to quickly and objectively identify energy improvements that offer maximum life-cycle cost (LCC) savings. FEDS determines an optimum set of cost-effective retrofits from a current database of hundreds of proven technologies. FEDS does not include building-integrated renewable energy conservation measures (ECMs) at this time. FEDS can be used to perform comprehensive assessments

\footnotetext{
4 Boiler Horsepower $=$ evaporation of 34.5 lbs. of water at $212^{\circ} \mathrm{F}$ into steam as $212^{\circ} \mathrm{F}$
} 
using other sources of capital (e. g. , energy savings performance contract or utility financing) with distinct economic inputs. If desired, the PNNL energy team can re-run the FEDS software using sitespecific alternative financing options and reassess the results. This reassessment was not requested, thus not performed and included in this report; however, a re-run of Feds was requested after the preliminary set of measures were reviewed to bring the estimates more in line with "actual" costs at a Category 2 nuclear facility. The revised Feds model included a fully burdened craft charge out rate and an escalation factor that reflects the challenges of working in a facility such as RPL facility that contains asbestos, radioactive materials, and beryllium.

The FEDS model was calibrated using the local weather and utility data for September 2012 - August 2013. More information on the calibration processes is included in Appendix B. The models were then run to estimate annual HVAC, lighting, service hot water, and miscellaneous end-use loads based on typical meteorological weather year, and to identify cost-effective retrofits. For retrofits not included in the FEDS model, such as irrigation and plug load reduction, other spreadsheet analysis tools were used. These other analysis tools were developed for the military's EISA assessment program and have been peer reviewed and used by other entities outside of PNNL.

Retrofit costs and savings estimates for ECMs were developed for projects that are LCC effective given the utility rates and current loads. ECMs screened for include:

- Boiler and Chiller Plant Improvements

- Service Hot Water

- Lighting Improvements

- Building Envelope Modifications

- Chilled Water Distribution Systems

- Refrigeration

- Electric Motors and Drives

- Renewable Energy Systems

- Water and Sewer Conservation Systems

- Appliance/Plug-Load Reduction

In addition to this report, F\&O will receive a complete record of the FEDS input and output files, as well as the Excel documentation for projects. The FEDS input files consist of the relevant building and equipment data collected and the assumptions made to perform the complex engineering analysis. The FEDS output files contain considerably more detail in support of project development. 


\subsubsection{Utility Rates}

Over the past several years, Mission Support Alliance (MSA) has provided RPL with Bonneville Power Administration (BPA) electricity; however, at the end of calendar year 2013, the electrical service for the Hanford 300 Area was transitioned over to the City of Richland. Unfortunately, the transition was not as smooth as hoped, and some meter reading issues were discovered for the months of November and December 2013. Likewise, MSA (a company that is responsible for the transmission and distribution of the BPA electricity on the Hanford Site) had some problems with their final September and October (2013) meter readings. Thus, it was recommended that analysis use 12 months' worth of historical data, which represented stable, "more accurate" costs and consumption figures, from September 2012 thru August 2013. The rates used for the analysis are discussed below.

Beginning November 3, 2013, the City of Richland replaced MSA, to provide electricity to RPL. RPL will be billed for electricity according to the City of Richland's Schedule 24 (Large General Service, for customers with a maximum demand between 300 and 1,000 kW). As of January 1, 2013, the rate schedule has a demand charge of $\$ 5.85 / \mathrm{kW}$ an energy charge of $3.12 \mathbb{\$} / \mathrm{kWh}$, and a power factor charge. These charges do not vary by time of day or season, and there is no ratchet used in the determination of billing demand (i. e. , the measured peak demand in a given month is the billing demand for that month, modified for power factor lower than 0. 95). FEDS uses the rate schedule parameters in the LCC. Other analysis tools use a blended rate, and \$0. 3112/kWh was used for the period of Sept. 2012 - Aug. 2013. The electrical consumption for this same time period was 7,313,573 kWh which includes the main RPL building, the chiller and the boiler annex.

The 300 Area is billed from a Cascade Natural Gas, Inc. natural gas meter that serves as the master meter for the entire 300 area. The RPL natural gas allocation comes from the PNNL gas meter located outside the RPL steam annex building. The effective rate for calendar year 2013 was $\$ 0.662 /$ therm, and the total usage based on calendar year 2013 was 81,343 therms.

The water and sewer services are provided by the City of Richland. These rates have varied considerably in the past, so similar to the electrical rates above, the basis for the rates and consumption were recommended by the PNNL Utility Program Manager. The recommended rate for this analysis is the rate charged to Washington Closure Hanford (WCH) for the 300 Area which is \$1. 05/ccf (\$1. 404/Kgal) for water and \$2. 15/ccf (\$2. 87/Kgal) for sewer.

In addition, as part of the 1997 ESPC contract, Johnson Controls Inc. (JCI) is responsible for the operation and maintenance (O\&M) of the boiler annex. The O\&M cost paid to JCI varies from year to year but was $\$ 19,469$ per month for FY13, for an annual fee of $\$ 233,628$ and $\$ 14,010$ per month for FY14, which will be adjusted, as required, based on the gas consumption later in the year. This seems excessive and as more of the buildings in the 300 area become obsolete and are demolished, this cost may increase, unless renegotiated. 


\subsection{RPL Energy and Water Conservation Measures}

The following section describes the ECMs identified and recommended during the assessment. Interactive effects are also evaluated as part of the optimization process so that energy savings are not double counted or undercounted. Table 4 includes a summary of the energy savings, O\&M savings and LCC economics. This table includes measures that were determined to be cost-effective.

Table 4. Expanded Summary of Measures by End Use

\begin{tabular}{|c|c|c|c|c|c|c|c|}
\hline ECM Measure & $\begin{array}{c}\text { Total } \\
\text { Energy } \\
\text { Savings } \\
\text { (MMBtu/yr) }\end{array}$ & $\begin{array}{c}\text { Total } \\
\text { Water } \\
\text { Savings } \\
\text { (Kgal/yr) }\end{array}$ & $\begin{array}{c}\text { Annual } \\
\text { O\&M } \\
\text { Cost } \\
\text { Savings } \\
\text { (\$/yr) }\end{array}$ & $\begin{array}{c}\text { Annual } \\
\text { Energy } \\
\text { Cost } \\
\text { Savings } \\
\text { (\$/yr) }\end{array}$ & $\begin{array}{c}\text { Total } \\
\text { Annual } \\
\text { Savings } \\
\text { (\$/yr) }\end{array}$ & $\begin{array}{c}\text { Capital } \\
\text { Costs }\end{array}$ & $\begin{array}{c}\text { Simple } \\
\text { Payback } \\
\text { (yr) }\end{array}$ \\
\hline
\end{tabular}

Lighting

\begin{tabular}{llccccc}
\hline $\begin{array}{c}\text { Replace Exit } \\
\text { Signs }\end{array}$ & 1 & $\$ 743$ & $\$ 8$ & $\$ 751$ & $\$ 8,8064$ & 10.7 \\
$\begin{array}{l}\text { Replace } \\
\text { HLRF }\end{array}$ & 2 & $\$ 398$ & $\$ 89$ & $\$ 487$ & $\$ 8,083$ & 16.5 \\
Lighting & & & & & & \\
\hline
\end{tabular}

Building Envelope

\begin{tabular}{|c|c|c|c|c|c|}
\hline $\begin{array}{c}\text { Install Second } \\
\text { Floor } \\
\text { Vestibule }\end{array}$ & 210 & $\$ 1,919$ & $\$ 1,919$ & $\$ 22,968$ & 12. 0 \\
\hline
\end{tabular}

HVAC

\begin{tabular}{ccccccc}
\hline $\begin{array}{c}\text { Convert } \\
\text { Steam System } \\
\text { to Hot Water }\end{array}$ & 7,019 & $(\$ 5,100)$ & $\$ 57,418$ & $\$ 53,067$ & $\$ 524,680$ & 9.9 \\
\hline
\end{tabular}

\begin{tabular}{|c|c|c|c|c|c|c|c|}
\hline $\begin{array}{c}\text { Apply } \\
\text { Temperature } \\
\text { Setback }\end{array}$ & 3,544 & & & $\$ 25,103$ & $\$ 25,103$ & $\$ 200$ & 0.0 \\
\hline $\begin{array}{l}\text { Install VFDs } \\
\text { on Supply and } \\
\text { Exhaust Fans }\end{array}$ & 5,190 & & & $\$ 50,594$ & $\$ 50,594$ & $\$ 79,994$ & 1. $6^{6}$ \\
\hline Total & 16,049 & 0 & $(\$ 3,959)$ & $\$ 135,131$ & $\$ 131,923$ & $\$ 643,989$ & 4.9 \\
\hline
\end{tabular}

${ }^{5}$ High level assessment based on converting a central steam plant to a decentralized hot water system

${ }^{6}$ The energy savings were determined by the FEDS model based on adding variable frequency drives (VFD)s to the existing supply and exhaust fans; the capital cost and payback were hand calculated based on these savings. However, this ECM is superseded by another more detailed analysis which recommended new fans and VFDs with harmonic filters. This approach took into account RPL's long term mission ensuring a life expectancy of $30+$ years for the exhaust system while mitigating any harmonic disturbances. 


\subsection{Measures Identified Using FEDS}

The FEDS simulation did not return many large capital retrofits, which was expected because the RPL energy unit costs are relatively low with high craft labor costs to safely implement upgrades.

To carry out the unique mission of RPL, there are mandatory operational requirements that must be met such as the large supply and exhaust fan systems serving the RPL lab spaces must run continuously, irrespective of the day of the week or holidays. Likewise, the fume hoods ventilation also operate continuously because of radiological and chemical hazards in the labs and hoods. Thus, typical building energy conservation measures involving curtailing HVAC equipment runtimes cannot be deployed at RPL.

The following sections identify the energy and water conservation measures (ECMs and WCMs) and include an assessment of the existing conditions in the affected group of buildings, a description of each ECM or WCM, and a summary of the economics.

\subsubsection{Replace Exit Signs with Electroluminescent Exit Signs}

RPL has 34 LED exit signs throughout the facility. Because these fixtures need to be on, regardless of occupancy, it is recommended that these fixtures be upgraded to a more efficient technology such as electroluminescent as funding permits. It is calculated that this retrofit yields a cost savings of $\$ 751$, with a simple payback of 10.7 years and a SIR of 1. 6 .

\subsubsection{Replace Metal Halide Lighting in HLRF}

A majority of the High Level Radiochemistry facility (HLRF) space is lit by 11 metal halide fixtures. It was suggested by RPL staff that all the lighting in HLRF needs a comprehensive redesign and replacement including not just the High Bay but also room 604, the 603 manipulator shop, and the truck lock (610).

To reduce the energy consumption in the majority of the HLRF area, and allow the lighting level to remain the same, the metal halide fixtures should be replaced by 3F32ST8 fixtures. Switching the metal halide lights for super T8s is expected to yield an electrical savings of 7 MMBtu per year. However, the decrease in the lighting load also decreases the amount of heat added to the space. Therefore, the heating load to the HLRF space will increase approximately 3 MMBtu per year, resulting in a total energy savings of 4 MMBtu per year. This measure has a simple payback of 16.5 years and a SIR of 1. 0 .

\subsection{Measures Identified Outside of FEDS}

The following additional measures were identified for more analysis beyond the FEDS model. These measures included: (1) adding a second floor vestibule, (2) conversion from steam to hot water, and (3) temperature setbacks.

\subsubsection{Add a Second Floor Vestibule for Office Area}

It is recommended that a vestibule be added for the second floor entrance door \# 211, Figure 2. The intent of a vestibule is to reduce infiltration of air, thereby addressing energy conservation and comfort 
issues for occupants located near the entrance door. Vestibules can reduce the infiltration losses (or gains) from wind and stack effects by creating an air lock entry. It was noted by RPL staff that there may be an additional benefit to reworking the $2^{\text {nd }}$ floor door by adding a vestibule. The rework of the door will allow the proximity card reader to move the inside door. The exterior door has been a serious maintenance issue because as the weather gets warm the door warps from heat and sometimes doesn't latch, resulting in security issues and added maintenance cost; thus removal of the proximity system reader from the outside door should curtail maintenance costs.

This is a main entrance on the west side of the building for office spaces serving approximately 59 occupants. Two vestibules were added on the first floor on the east and west side of the building within the last 6 months. These additions have reduced drafts, stabilizing the building pressure.

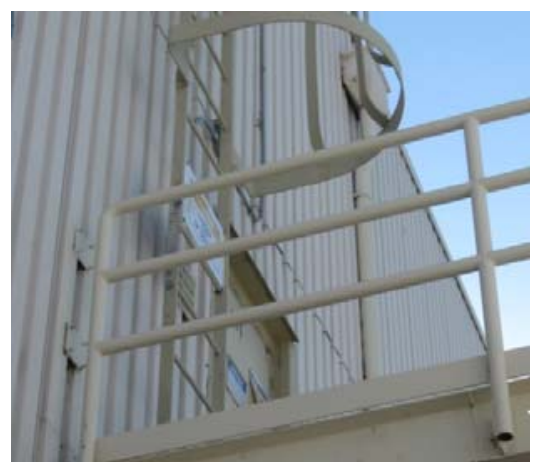

Figure 2. Second Floor Vestibule Location

Table 5 shows a breakdown of savings anticipated from installing a vestibule on the second floor, with a total energy savings of 209. 9 MMBtu per year and \$1,919 per year (See Appendix E for the assumptions and calculations). These savings result in a simple payback period of approximately 12 years.

Table 5. Savings from Installing a Second Floor Vestibule

\begin{tabular}{|c|c|c|c|c|c|}
\hline $\begin{array}{c}\text { Heating } \\
\text { Source }\end{array}$ & $\begin{array}{c}\text { Heating } \\
\text { Energy } \\
\text { Savings } \\
\text { (MMBtu/yr) } \\
\end{array}$ & $\begin{array}{c}\text { Cooling } \\
\text { Energy } \\
\text { Savings } \\
\text { (MMBtu/yr. ) } \\
\end{array}$ & $\begin{array}{c}\text { Total Annual } \\
\text { Cost Savings } \\
(\$ / y r .) \\
\end{array}$ & $\begin{array}{c}\text { Capital } \\
\text { Cost } \\
\end{array}$ & $\begin{array}{c}\text { Simple } \\
\text { Payback } \\
\text { (yrs.) }\end{array}$ \\
\hline Electric & 197. 89 & 12. 02 & $\$ 1,919.42$ & $\$ 22,968$ & 12. 0 \\
\hline
\end{tabular}




\subsubsection{Convert steam system to hot water}

The 25-year ESPC ends in approximately 8 years. In the next few years, it would be prudent to develop a strategy that would complement the RPL mission, and include favorable negotiation of the disposition of existing assets. Over the years, investments have been made to extend the life of the RPL facility and upgrade the operational processes. However, a considerable portion of the remaining equipment and systems are old and in need of major repairs or replacement. Further, based on current operation, it seems that the high pressure steam system originally installed is no longer required, and to be efficient, the pressures and temperatures should only be as high as required for the end use. High pressure steam systems result in higher heat losses, and require a complex condensate system. The steam and condensate systems are subject to steam trap problems and piping and pump corrosion, which tends to reduce or eliminate the amount of condensate return to the boilers, driving up costs. Based on the run time hours of the condensate pumps, it appears this is the case.

A high level simulation was performed in FEDS to confirm the idea of converting the central steam plant to a hot water system. The model assumes a method to accomplish this is to decentralize the plant and place the boilers, in this case a hot water boiler near the consumer. Thereby gaining boiler efficiency and reducing lines losses; yet adding a slight increase in operations and maintenance (O\&M) costs (estimated by FEDs to be \$5100/year) since the boilers will then be managed by RPL instead of the ESPC contract. Regardless of the exact strategy to convert from steam to hot water, it is recommended to continue with the incremental dropping of the steam pressures (as the astute RPL operations staff have initiated) to a lower pressure; yet without introducing operational problems, and make future modifications to eliminate the direct steam consumers beginning with the low pressure consumers by:

- Remove the supply fan \#5 (SF-5) system and enable shutting down the low pressure steam leg that routes through basement from second floor, along with associated pumps and steam traps. This would eliminate a $\$ 5,000$ to $\$ 10,000$ fee associated with handling and dumping the condensate because of its' potential to be radioactive waste. About $\$ 1 \mathrm{~K}$ is spent to test the condensate before sending to waste treatment, and this testing is repeated at least five times per heating season.

- An alternative for the areas that are fed by SF-5 and any other active steam consumers would need to be investigated. However, some of the steam consumers have been eliminated, for example, the RPL staff have stated that the craft shop (room 206) RTU has a steam preheat coil is no longer active and was abandoned in place.

- It is recommended that the large supply fans be reviewed to determine is they have enough capacity to cover the common areas fed by SF-5, which would require extending ducts, and adding zone reheat and re-cool coils as needed with zone control. It is also possible that the small chiller system located on the SW corner of the building that presently serves the front office/lobby areas could provide the chilled water for cooling coils. Using these existing sources would keep the capital and O\&M costs down.

Once the low pressure steam is eliminated, a path to convert the remaining steam system from high pressure steam to hot water can be considered and evaluated. Currently, the high pressure steam is converted to hot water via heat exchangers for heating coils; thereby introducing a potential loss of anywhere from $1 \%$ to $3 \%$, so ideally, they should be eliminated. If the heat exchangers are needed or 
desired for isolation purposes, larger buildings can use plate-and-frame heat exchangers, which because of their large surface area to volume ratios, are economical for low temperature hot water (LTHW) applications; these LTHW systems are defined per Cold Regions Research and Engineering Laboratory (CRREL) Report by Army Corp of Engineers (Phetteplace).

The existing CB steam boilers were expected to be in the range of $80 \%$ to $84 \%$ efficient when installed in 1997; therefore, it is very unlikely that they are operating that efficiently now. Further, based on 2013 gas consumption, only one boiler is required (with one in standby) and that boiler operates on average, less than $50 \%$ of the time. Although this is an average and weather dependent, the water consumption into the annex confirms that the boilers are underutilized.

The option to retrofit the existing boilers to hot water has been considered by Johnson Controls Inc. (JCI). Cole Industrial has provided a quote in 2011 to JCI for \$22,000; which inflated to 2015 ( 3\% per year) would be $\$ 25,000$ to retrofit the boiler only, with no other labor or equipment (such as pumps and piping, valves, etc. ) included, and the efficiency of the boiler would be the same as today $~ 80 \%$ or lower. This option has a low initial cost for the boiler retrofit; but after modifying the system to accommodate the hot water instead of steam; the costs would rise considerably. In addition, if the manufacturer cannot guarantee optimal boiler efficiency and/or the option requires an extension of the ESPC contract, it is not expected to be a viable alternative.

It is recommended to consider a new boiler, such as a condensing boiler. Using hot water has many advantages and given the right conditions (hot water return temperatures below $140^{\circ} \mathrm{F}$ ) a condensing boiler can provide 95\% efficiency. Based on the existing range of the hot water set points, it appears that a condensing boiler may be an appropriate choice for RPL. It is understood that there are many factors to address to make the conversion; for instance the preheat and reheat coils in the main supply air handlers may need to be replaced if the existing coils are scaled but new coils would not only provide better heat transfer but would reduce pressure drop across the coils. Therefore, a thorough evaluation would have to be undertaken, but the enhanced system efficiencies could provide a good payback and the reduction of O\&M costs associated with the elimination of equipment and a simplified system would provide additional benefits.

Ideally a new small boiler could be located close to the process (second floor mechanical room) to facilitate allow cost installation, reduction of line losses, and potential elimination of extra equipment (less O\&M); however, RPL is a unique facility that has operating criteria that only allows for a limited amount of flammable gases within the building. Therefore, any boiler would have to reside in the boiler annex or another similar building built to house the small boiler(s). Even though there will still be line losses associated with the boiler upgrade, there will be less of a loss since there will be less of a temperature difference between what is inside and outside of the steam/water lines.

Based on the measured data that indicates a smaller boiler would be sufficient to meet RPL needs, Cleaver Brooks recommended a CB ClearFire C 2,500 MBtu ${ }^{7}$. However, in this boiler family, the range goes as high as 5,000 MBtu, and there are many other models and manufacturers to choose from for this technology.

A condensing boiler assessment was conducted for GSA in 2010. The assessment replaced two natural-gas-fired non-condensing fire-tube boilers with four boilers of the $2500 \mathrm{MBtu}$ size. The

\footnotetext{
${ }^{7}$ http://www.cleaver-brooks.com/Products-and-Solutions/Boilers/Commercial-Condensing/ClearFire-C/Index.aspx
} 
condensing boilers were shown to operate at $~ 93.5 \%$ efficiency and had reduced natural gas consumption by $\sim 14 \%$. The results were shown in two options:

- The Retrofit option: when the existing boilers have considerable life remaining so replacement is optional; replacing with condensing boilers led to a SIR of 0.25

- The Replace at End of Life option: the existing boilers are at the end of their useful economic life and need to be replaced; replacing with condensing boilers led to a SIR of $1.78^{8}$

To simulate this measure in FEDS, the boiler system was set up as a central plant to account for losses in the steam to hot water conversion and the losses in the lack of condensate return. After the model was calibrated to the provided utility data, the model was adjusted by abandoning the central plant to make up for the line losses in the current system. This analysis method ${ }^{9}$ resulted in an energy savings of 7,019 MMBtu per year and \$53,067 per year, with a simple payback of 9. 9 years. These savings would be the result of upgrading to a boiler with an efficiency of at least $84 \%$

Thus, the strategy for RPL would include a review of existing assets, the ESPC contract terms, and operating process tactics. If an assessment of condensing boilers is implemented, there are several reports with guidelines (Office of the Deputy Prime Minister) to assist in the evaluation, and GSA has lessons learned support the cost effectiveness of this type of upgrade (GSA).

\subsubsection{Temperature Setbacks}

RPL's HVAC system is currently on PNNL's building automation system (BAS) through the Building Operation Control Center (BOCC). It was discovered during a meeting at BOCC in January, that the zone temperature setbacks had been overridden to $70^{\circ} \mathrm{F}$, which also disallows the zone temperatures to change during unoccupied periods. These zone setbacks should be periodically reviewed and verified. Currently, BOCC sets all PNNL building zone temperatures according to Table 6.

Table 6. Suggested Building Temperature Set Points

\begin{tabular}{lcc}
\hline & Heating Season & Cooling Season \\
\hline Occupied Hours & $68^{\circ} \mathrm{F}$ & $72^{\circ} \mathrm{F}$ \\
Unoccupied Hours & $60^{\circ} \mathrm{F}$ & $80^{\circ} \mathrm{F}$ \\
\hline
\end{tabular}

Unlocking the fixed set point of $70^{\circ} \mathrm{F}$, and re-implementing the above temperature set points is expected to save approximately 3,544 MMBtu per year and \$25,103 per year.

Upon further investigation it was suggested that one of the zones had their heating setbacks overridden because the space took too long to recover from the nighttime setback. This should be investigated and insufficiencies in the zone infrastructure be corrected so in the future setbacks can be implemented that can save energy. Further, engage in discussions with PNNL energy experts to determine if other options such as advanced BAS code could be employed to produce energy savings.

\footnotetext{
8 http://www.gsa.gov/portal/mediaId/163539/fileName/GPG Condensing Boiler__FINAL DRAFT 4-15-13 508.action; downloaded $2 / 26 / 2104$

${ }^{9}$ This method uses a high efficiency gas boiler, not a condensing boiler.
} 
It is also recognized that other strategies simulating setbacks are being used effectively, such as during the cooling season, the chillers are turned off when the outside air temperatures drop below a target set point (typically $78 \mathrm{deg}$. ). These strategies are implemented to maintain the building temp at 72 $\pm 7^{\circ} \mathrm{F}$, while making sure that special lab spaces with sensitive equipment that could experience calibration shifts due to changes in the room temperature are not detrimentally affected.

\subsubsection{Add Variable-Frequency Drives (VFDs) for Supply and Exhaust Fans}

Installing VFDs, such as those proposed for the four large exhaust fans (150 hp each) and all four large supply fans (60 hp each) were evaluated using the FEDs model. The savings for VFD-driven equipment is from the summed savings of running (4) parallel ducted systems in tandem and the resulting power that results from the Affinity Laws (cube reduction in power for each RPM\% reduction). In addition, the VFDs would enable a change in the operation of the fans; to run the fans at lower speeds decreasing pressure drop across coils and filters, which should make the heat recovery system work better. The latter benefits were not accounted for the FEDs model.

There are also other inherent benefits that FEDs was unable to estimate in the savings and payback calculations that should result in reduced capital replacement and O\&M costs; such as:

o The elimination of air leakage past the non-running supply and exhaust fans.

o The reduction of wear on the fans, due to the ability to run all supply and exhaust fans at lower RPMs. These benefits include reduced wear on motor windings, bearings, shafts, belts and pulleys; extending equipment life.

Although FEDS cannot quantify all benefits of an ECM, it is a tool that can determine cost effective energy efficiency measures in an all-encompassing manner. The FEDS analysis for the installation of VFDs estimated a reduction in electricity of 7,047 MMBtu, with an increase in natural gas usage of 1,856 MMBtu for a total energy savings of approximately 5,190 MMBtu per year and \$50,594 per year ${ }^{10}$.

After using FEDs to generate savings and a payback for this ECM, it was brought to our attention that an evaluation had been completed in September of 201311 which concluded that to meet RPL's long term mission it would be better to replace the supply and exhaust fans, while adding VFDs with harmonic filters. This comprehensive approach ensures a life expectancy of 30+ years for the exhaust system while mitigating any harmonic disturbances. This alternative would cost \$1. 6 to \$1. 9 million, with an annual savings of $\$ 87,716$ resulting in a $15-20$ year payback.

Both FEDS and the "Alternative Analysis” evaluation determined that this type of ECM would result in significant savings. However, since the FEDS model cannot adequately address issues such as harmonics it is recommended that all the ECMs/WCMs proposed are re-evaluated considering long term goals, unique hazards, infrastructure life expectancy and any other specific characteristics associated with the facility.

\footnotetext{
10 These savings are evaluated with the assumption that the previous measures have been implemented to avoid "double counting” savings throughout the analysis. Installing VFDs with RPL in its current condition shows a savings of 4,162 MMBtu per year and \$41,009 per year.

11 Alternatives Analysis, Building 325 Exhaust and Supply Fan VFD Installation; S704539-TECH-PM-001; Revision 0, September 2013
} 


\subsection{Additional ECMs and WCMs for Consideration}

The following section describes areas that were evaluated but not included in the main project list because they were either low priority or not cost effective. These projects may become cost-effective as energy prices increase, spaces are renovated, and building infrastructure and/or equipment are replaced at end of life. Table 7 displays the expected savings and project costs for each measure.

Table 7. Additional ECMs and WCMs for Consideration

\begin{tabular}{|c|c|c|c|c|c|c|c|c|}
\hline Measure & $\begin{array}{c}\text { Total Energy } \\
\text { Savings } \\
\text { (MMBtu/yr) }\end{array}$ & $\begin{array}{c}\text { Total } \\
\text { Water } \\
\text { Savings } \\
\text { (Kgal/yr) }\end{array}$ & $\begin{array}{c}\text { Annual } \\
\text { Energy Cost } \\
\text { Savings (\$/yr) }\end{array}$ & $\begin{array}{c}\text { Annual } \\
\text { Water } \\
\text { Cost } \\
\text { Savings } \\
\text { (\$/yr) } \\
\end{array}$ & $\begin{array}{c}\text { Annual } \\
\text { O\&M } \\
\text { Savings } \\
\text { (\$/yr) }\end{array}$ & $\begin{array}{c}\text { Total } \\
\text { Annual } \\
\text { Savings } \\
\mathbf{( \$ / y r )} \\
\end{array}$ & $\begin{array}{c}\text { Capital } \\
\text { Costs }\end{array}$ & $\begin{array}{c}\text { Simple } \\
\text { Payback } \\
\text { (yr) }\end{array}$ \\
\hline \multicolumn{9}{|c|}{ Building Envelope } \\
\hline $\begin{array}{l}\text { Upgrade South } \\
\text { Windows }\end{array}$ & 50 & 0 & $\$ 403$ & $\$ 0$ & $\$ 0$ & $\$ 403$ & $\$ 27,234$ & 67.6 \\
\hline $\begin{array}{c}\text { Upgrade Roof } \\
\text { Insulation } \\
\end{array}$ & 957 & 0 & $\$ 9,555$ & $\$ 0$ & $\$ 0$ & $\$ 9,555$ & $\$ 293,619$ & 30.7 \\
\hline \multicolumn{9}{|c|}{ Lighting } \\
\hline $\begin{array}{c}\text { Lighting } \\
\text { Occupancy } \\
\text { Sensors } \\
\end{array}$ & 716 & 0 & $\$ 18,057$ & $\$ 0$ & $\$ 0$ & $\$ 18,057$ & $\$ 162,180$ & 9. 0 \\
\hline $\begin{array}{c}\text { Replace T12 } \\
\text { Lighting } \\
\end{array}$ & 2. 5 & 0 & $\$ 23$ & $\$ 0$ & $\$ 65$ & $\$ 88$ & $\$ 7,308$ & 83.0 \\
\hline \multicolumn{9}{|c|}{ HVAC } \\
\hline $\begin{array}{c}\text { HVAC Small } \\
\text { Motor } \\
\text { Upgrades } \\
\end{array}$ & 505 & 0 & $\$ 6,097$ & $\$ 0$ & $\$ 0$ & $\$ 6,097$ & $\$ 302,508$ & 49.6 \\
\hline \multicolumn{9}{|c|}{ Other } \\
\hline $\begin{array}{c}\text { Smart Power } \\
\text { Strips }\end{array}$ & 52 & 0 & $\$ 472$ & $\$ 0$ & $\$ 0$ & $\$ 472$ & $\$ 21,143$ & 44.8 \\
\hline \multicolumn{9}{|c|}{ Water } \\
\hline $\begin{array}{c}\text { Toilet } \\
\text { Replacement }\end{array}$ & 0 & 81 & $\$ 0$ & $\$ 346$ & $\$ 0$ & $\$ 346$ & $\$ 7,431$ & 21.5 \\
\hline $\begin{array}{c}\text { Urinal } \\
\text { Replacement }\end{array}$ & 0 & 21 & $\$ 0$ & $\$ 90$ & $\$ 0$ & $\$ 90$ & $\$ 4,527$ & 50.1 \\
\hline $\begin{array}{c}\text { Faucet } \\
\text { Replacement }\end{array}$ & 14 & 42 & $\$ 219$ & $\$ 179$ & $\$ 0$ & $\$ 398$ & $\$ 188$ & 0.5 \\
\hline $\begin{array}{l}\text { Showerhead } \\
\text { Replacement }\end{array}$ & 4 & 11 & $\$ 70$ & $\$ 48$ & $\$ 0$ & $\$ 118$ & $\$ 167$ & 1.4 \\
\hline Total & 2,298 & 155 & $\$ 34,896$ & $\$ 663$ & $\$ 65$ & $\$ 35,624$ & $\$ 826,305$ & 23. 2 \\
\hline
\end{tabular}




\subsubsection{Install Commercial Style, High Performance Aluminum Frame Double Pane Argon/Low-Gain Windows}

The facility has two sets of windows on the south face of the building, as shown in Figure 3. South Face of RPL The same type of windows are in a few other locations around the building, as seen on the left side of Figure 3. During the audit, these windows were defined as having aluminum frames, double pane, with a reflective coating. It is recommended to replace these windows with a higher performance window to help reduce infiltration rates and solar gains.

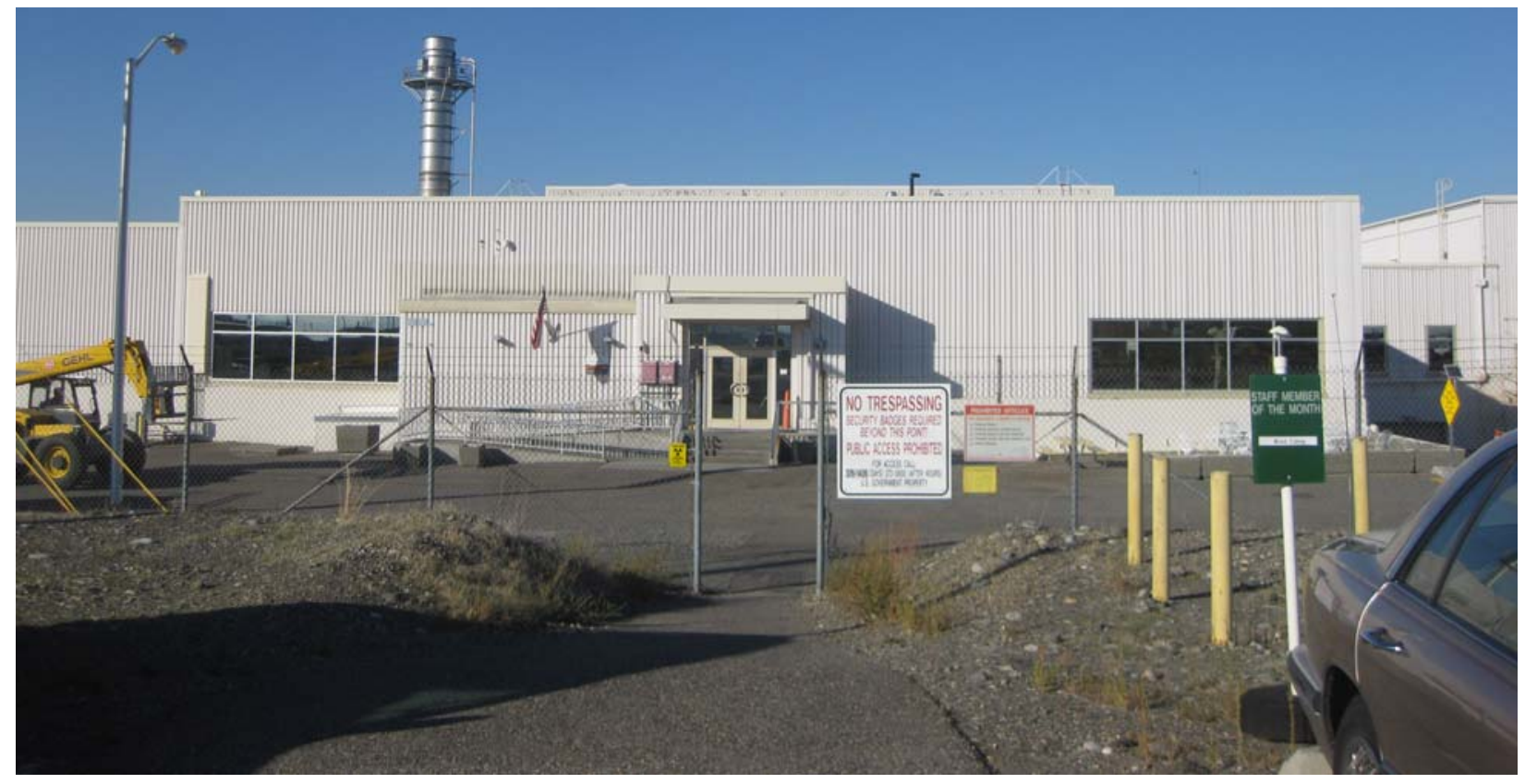

Figure 3. South Face of RPL 


\subsubsection{Increase Roof Insulation}

Although the current condition of the roof insulation was not measured during the audit, FEDS was able to estimate the roof insulation R-value based on the construction and age of the building. It is estimated that the current insulation has an average R-value of 8. 90, and that it should be increased to an $\mathrm{R}$-value of 19. 0 . This complements the fact that during the walk down of the building it was observed that the building roof and envelope was old and leaky. In addition, we were informed that the roof had been repaired over the years in several locations.

\subsubsection{Lighting Occupancy Sensors}

Currently, there are a few lighting occupancy sensors in limited areas at RPL. However, during the walkthrough audit, it was observed that many locations were lit while unoccupied. However, according to the RPL staff, some of these spaces may already be configured for occupancy sensors; thus there may be other reasons for the observations made during the walk down of the facility. It is possible some of the occupancy sensors may have failed, not functioning properly, have been over ridden or set-up for a significantly long period of vacancy. It is recommended to periodically check the sensors to ensure proper operation, timer setting and/or automatic configuration.

In addition, the hourly profile (explained in detail in Appendix A) reveals that there is only a slight variation in electrical load during different times of the day, indicating that a large majority of the building load remains constant, regardless of when the building is occupied. Although it is recognized that the primary reason for the constant building load is the continuous running of the large exhaust and supply fans, installing lighting occupancy sensors throughout the remainder of the facility will assist in reducing lighting utilization and electrical load.

\subsubsection{Replacing T12 Lighting Fixtures}

During the walkthrough audit, auditors counted approximately 20 T12 fixtures throughout the facility. After performing an analysis on the replacement of the T12 lights, a replacement to a more efficient lighting source was determined to not be cost effective at this time, largely in part because of the low utility rate and low quantity of fixtures. However, it is suggested to replace these fixtures as they wear out, or as the light bulbs burn out.

\subsubsection{HVAC Motor Upgrade}

The plan to sustain RPL's infrastructure should include upgrading older equipment to more efficient equipment. The average age for HVAC motors is approximately 20 years, which is the time when motor replacement should be considered. When purchasing a new motor, energy efficiency should be a major consideration; Rewinding is also an option, but usually not as effective at gaining major efficiency improvements as a new motor. Although there is a capital cost associated with a new motor, the annual energy cost of running a motor is usually many times greater than its initial purchase price. For example, even at the relatively low energy rate of $\$ 0$. 04/kWh, a typical 20-horsepower (hp) continuously running motor uses almost $\$ 6,000$ worth of electricity annually, about six times its initial purchase price. 
The following are motor upgrade suggestions to improve efficiency:

1. Upgrade the motors for the two preheat pumps

2. Upgrade the motors for the two heat recovery pumps

3. Upgrade the motors for the two reheat pumps

4. Upgrade the motors for the four large exhaust fans

5. Upgrade the motors for the four large supply fans

Motor Master+ International (V 1. 1. 5) was used to determine motor replacement savings. The full outputs from Motor Master can be reviewed in Appendix F. Table 8 displays a summary of the approximate savings from replacing the motors listed above. Note: The motors chosen for comparison experience the highest savings. Less expensive motors may be selected for quicker payback periods. Also, these numbers were calculated based on average annual run-times. Some motors may experience more or less of a savings depending on their use during seasonal and shoulder months.

Table 8. Savings Summary for HVAC Motor Replacement

\begin{tabular}{|c|c|c|c|c|c|c|c|c|}
\hline $\begin{array}{c}\text { Current } \\
\text { Motor }\end{array}$ & $\begin{array}{l}\text { Size } \\
\text { (hp) }\end{array}$ & Qty. & $\begin{array}{c}\text { Current } \\
\text { Efficiency } \\
\text { Rating } \\
\end{array}$ & $\begin{array}{c}\text { Replacement } \\
\text { Efficiency } \\
\text { Rating } \\
\end{array}$ & $\begin{array}{l}\text { Replacement } \\
\text { Motor Cost }^{12}\end{array}$ & $\begin{array}{c}\text { Total } \\
\text { Energy } \\
\text { Savings } \\
\text { (kWh/yr ) }\end{array}$ & $\begin{array}{c}\text { Total } \\
\text { Cost } \\
\text { Savings } \\
(\$ / y r)\end{array}$ & $\begin{array}{c}\text { Simple } \\
\text { Payback } \\
\text { Period } \\
\text { (yr) }\end{array}$ \\
\hline \multicolumn{9}{|l|}{$\begin{array}{l}\text { Pre Heat } \\
\text { Pumps }\end{array}$} \\
\hline $\begin{array}{l}\text { US Motor } \\
\text { Lincguard }\end{array}$ & $\begin{array}{l}30 \\
50\end{array}$ & $\begin{array}{l}1 \\
1\end{array}$ & $\begin{array}{l}90 \% \\
91.7 \%\end{array}$ & $\begin{array}{l}93.4 \% \\
93.2 \%\end{array}$ & $\begin{array}{l}\$ 7,797 \\
\$ 5,952\end{array}$ & $\begin{array}{l}5,638 \\
4,233\end{array}$ & $\begin{array}{l}\$ 233 \\
\$ 174\end{array}$ & $\begin{array}{l}11.15 \\
11.40\end{array}$ \\
\hline \multicolumn{9}{|l|}{$\begin{array}{l}\text { Reheat } \\
\text { Pumps }\end{array}$} \\
\hline \multicolumn{9}{|l|}{$\begin{array}{l}\text { Heat } \\
\text { Recovery } \\
\text { Pumps }\end{array}$} \\
\hline US Motor & 30 & 2 & $90 \%$ & $93.4 \%$ & $\$ 11,904$ & 11,276 & $\$ 466$ & 11.40 \\
\hline \multicolumn{9}{|l|}{ Supply Fans } \\
\hline $\begin{array}{l}\text { Westinghouse } \\
\text { Motor }\end{array}$ & 60 & 4 & $90 \%$ & $94.7 \%$ & $\$ 151,635$ & 62,704 & $\$ 2,584$ & 22. 05 \\
\hline \multicolumn{9}{|l|}{ Exhaust Fans } \\
\hline Lincguard & 150 & 4 & $94.1 \%$ & $95.9 \%$ & $\$ 109,626$ & 55,632 & $\$ 2,292$ & 14. 14 \\
\hline Totals & & & & & $\$ 302,508$ & $\begin{array}{l}\text { 147,949 } \\
\text { kWh/yr. }\end{array}$ & $\begin{array}{l}\$ 6,097 \\
\text { per yr. }\end{array}$ & 49.6 yrs. \\
\hline
\end{tabular}

\footnotetext{
12 Motor costs are dependent on Motor Master's 2010 figures for the purchase cost of a motor and cost of installation, plus 15\% was added to that figure to account for supervision, inspection, and overhead (SIOH) and to reflect 2013 market prices. The values from Motor Master have also been escalated by a factor of 2.5 to align with project costs at RPL.
} 


\subsubsection{Workstation Occupancy-Controlled Power Strips}

During the walkthrough audits, the assessment team noticed opportunities to save energy by installing occupancy-controlled (or "smart") power strips at workstations ${ }^{13}$. Smart power strips have a combination of controlled outlets (which turn off devices that are not being used) and uncontrolled outlets (which continuously deliver power to their devices).

Load-sensing strips have a master outlet (always on) to which a selected device is connected to monitor loads. The load sensor detects the decrease in current that occurs when the master outlet's device goes into standby mode. When the master outlet's device (e. g. , a computer) enters standby mode or is manually turned off by the user, the peripheral devices (e. g. , monitor, speakers, printer, and scanner) plugged into controlled outlets are automatically turned off. Peripheral devices for which the user never wants power to be automatically disconnected can be plugged into the uncontrolled (always on) outlets. Figure 4 shows an example of a load-sensing smart power strip.

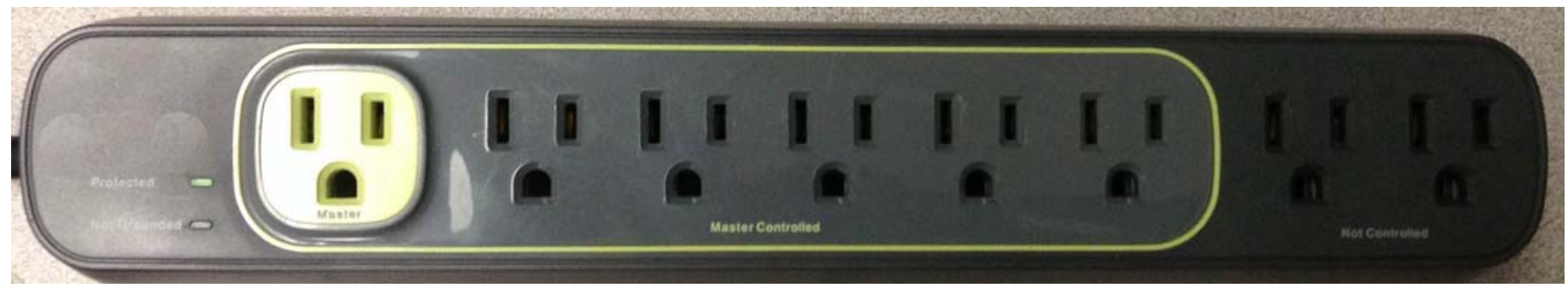

Figure 4. Example Load-Sensing Power Strip

The number of office workstations was estimated by combining the information gathered during the walkthrough with the PNNL Map Information Tool and querying the number of people who work in each building. The load-sensing strips are only being suggested in offices, not in the laboratories, but there may be an opportunity in the laboratories once the power strips are piloted in the offices.

Recommendations for installing smart power strips are as follows:

- install 53 workstation smart power strips in the first floor office spaces

- install 50 workstation smart power strips in the second floor office spaces

- install 40 workstation smart power strips in the basement office spaces.

Conservative estimates of savings were used to estimate the LCC for this project and it was assumed that occupants would install their own power strips at their workstations. Because of the low utility rate, this project has an SIR below 1, but when bundled with other projects, it could be implemented.

\subsubsection{Potable Water Use}

The potable water use at RPL includes the domestic plumbing fixtures in 325, as well as the cold process water that feeds the steam boilers residing in 325A. Total water use in FY12 was 674 hundred cubic feet, or 504,263 gallons, based on billing information. The assessment team performed an engineering estimate of the annual domestic fixture water use at RPL based on the assigned number of

\footnotetext{
${ }^{13}$ The retrofit described here involves occupancy-based control of the workstation devices (e.g., computer, monitor, speakers, printer, and scanner).
} 
building occupants, the known efficiency of the installed fixtures, and a range of assumed fixture uses per person per day (see Appendix D for additional description of the assumptions and calculations used to derive these estimates). Although some of the retrofits did not have favorable return on investment estimates they were all included to facilitate prioritizing which fixtures to replace when future upgrades are implemented. In addition, sub-metered data for the cold process water was provided so a water balance could be established for all the principal end uses at the time of the assessment.

Toilets are the largest component of the domestic water balance, accounting for 162 Kgal annually. The cold process water that includes the steam boilers also uses about $162 \mathrm{Kgal}$ annually based on submetered data ${ }^{14}$. Bathroom faucets are the next largest water end-use representing 64 Kgal annually, followed by leaks/losses/other that account for roughly $50 \mathrm{Kgal}$ per year (Table 9). These four uses comprise $87 \%$ of the total water consumption at RPL (Figure 5).

Table 9. Water Use by Major End-Use Category

\begin{tabular}{|c|c|c|}
\hline Water Use Category & $\begin{array}{l}\text { Average Water } \\
\text { Use } \\
\text { (gallons) }\end{array}$ & $\%$ of Total Use \\
\hline Toilets & 162,401 & $32 \%$ \\
\hline Process/Steam Boilers & 161,700 & $32 \%$ \\
\hline Bathroom Faucets & 63,570 & $13 \%$ \\
\hline Leaks/Losses/Other & 49,720 & $10 \%$ \\
\hline Urinals & 34,334 & $7 \%$ \\
\hline Showers & 27,905 & $5 \%$ \\
\hline Kitchen Faucets & 4,633 & $1 \%$ \\
\hline
\end{tabular}

\footnotetext{
${ }^{14}$ Insufficient information was available on the overall performance of the steam boiler system to develop any efficiency opportunities. Therefore, all of the conservation measures investigated were only for domestic plumbing fixtures.
} 


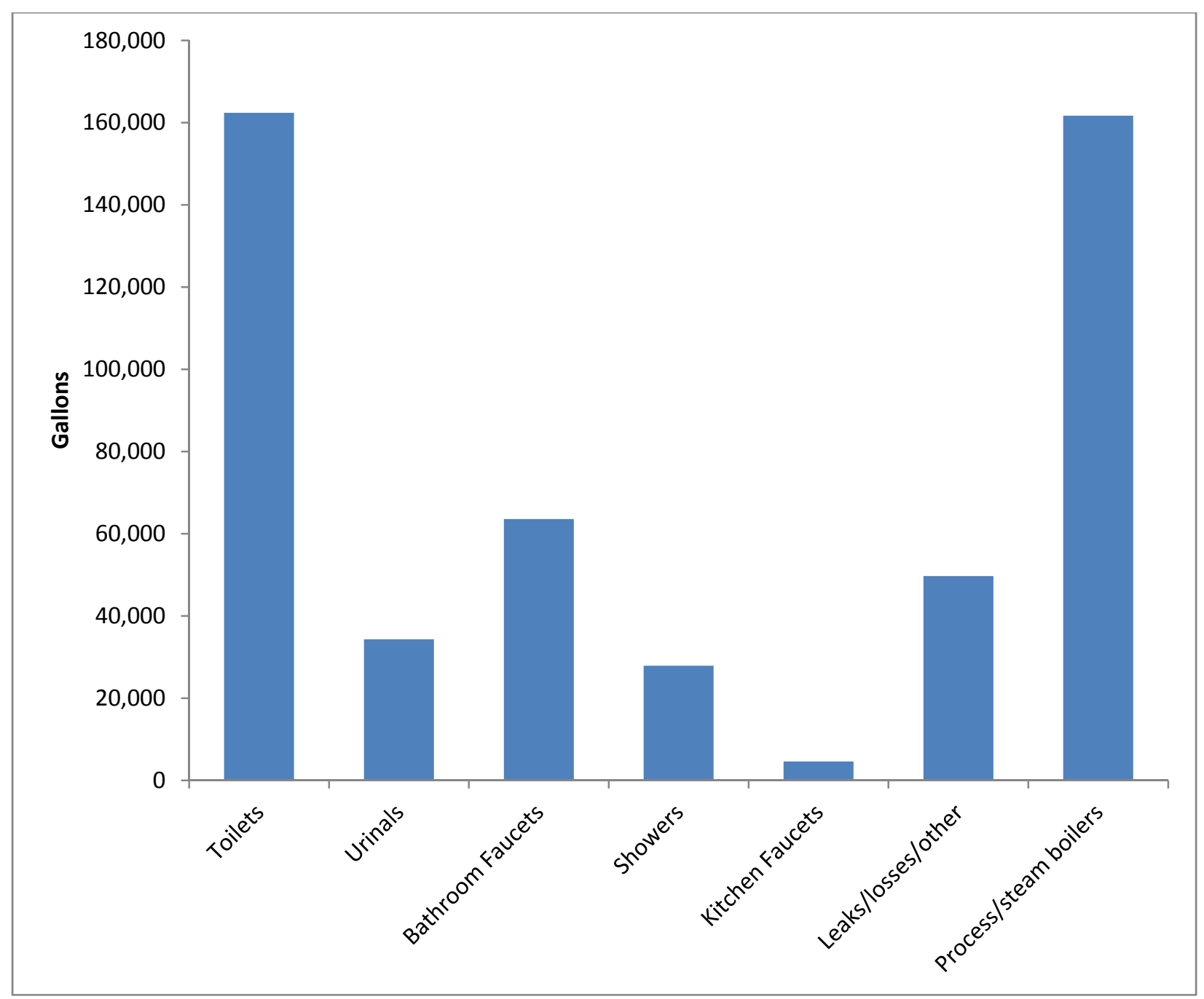

Figure 5. RPL Annual Water Use Breakout

During the walkthrough audits, the assessment team examined the domestic plumbing fixtures installed in the five men's restrooms and four women's restrooms throughout RPL. This included the restrooms in the HLRF area, as well as the fixtures in both the men's and women's locker rooms. Both locker rooms featured high efficiency toilets, faucets, and urinals, while the fixtures elsewhere in the building varied in their measured flow rates. To account for the difference between efficiency of the fixtures in the locker rooms and all of the other bathrooms, the building was divided into two use categories (the locker rooms, and all of the other bathrooms). Based on observed behavior during the walk-through audits, it was estimated that half the building occupants use the locker rooms while the other half use the remaining restrooms on a daily basis.

The restroom faucets varied in rating from 0.5 gallons per minute (gpm) to 2.2 gpm with the most efficient fixtures featured in the locker rooms. These ratings were confirmed by measurement with a flow bag. (A flow bag is a plastic bag that is calibrated for 5 seconds of flow and is marked with 1-gpm increments. )A flow rate of $0.5 \mathrm{gpm}$ is appropriate for a public restroom faucet; therefore none of the high efficiency faucets in the locker rooms (Figure 6) were considered for retrofits. A total of 20 bathroom faucets were observed during the audits, 8 of which were present in the locker rooms. The 12 
faucets in the regular restrooms are estimated to use $53 \mathrm{Kgal}$ annually, while the more efficient faucets in the locker rooms are estimated to use less than $11 \mathrm{Kgal}$ annually if each grouping is used daily by half of the building population. Two faucets were found to be missing aerators. One was in room 710 and the other was in room 605 in the HLRF area. The 12 faucets in the building restrooms were all evaluated for efficiency improvements. If they were replaced with high efficiency 0. 5-gpm units similar to those featured in the locker rooms, consumption would be reduced to $11 \mathrm{Kgal}$ each year, saving RPL $42 \mathrm{Kgal}$ annually in water use. This retrofit would cost \$188 and save \$398 annually in water and heating energy costs. The simple payback for this project is 0.5 years (Table 10).

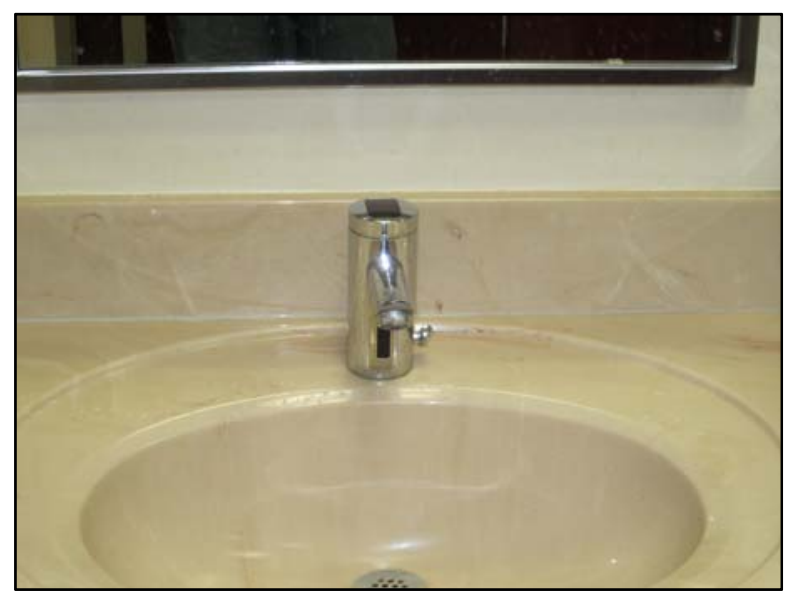

Figure 6. Efficient Locker Room Faucet

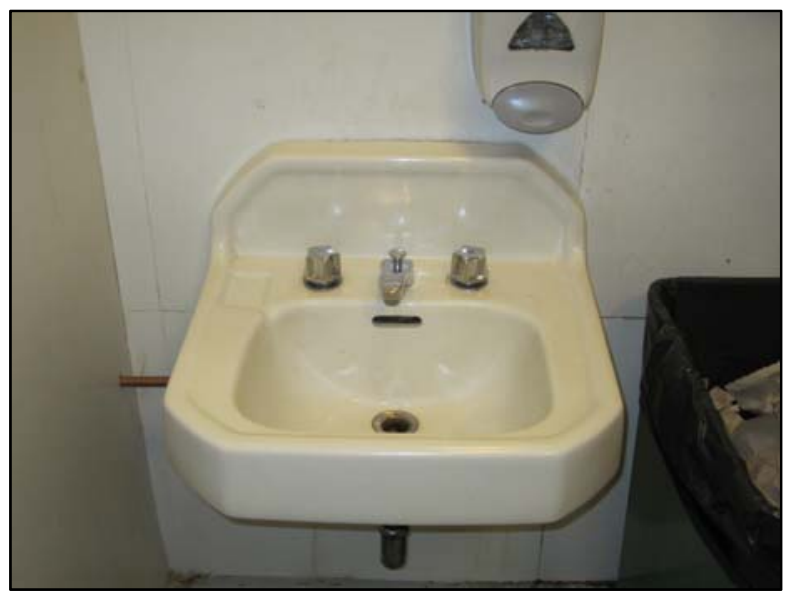

Figure 7. Inefficient Restroom Faucet 
The showerheads in the locker room were rated at 2.5 gpm (Figure 8). There were three showerheads in the men's locker room and three in the women's. All can easily be replaced with WaterSense ${ }^{15}$ labeled replacements that use no more than $1.5 \mathrm{gpm}$. That would reduce the estimated consumption by showers from $28 \mathrm{Kgal}$ per year to less than $17 \mathrm{Kgal}$ per year and would save over 4 million British thermal units (MMBtu) of hot water heating energy each year. The water use and LCC analysis assumes that 5\% of the occupants shower daily. ${ }^{16}$ The retrofit would cost \$167 and save \$118 in water and heating costs resulting in a simple payback of 1.4 years (Table 10).

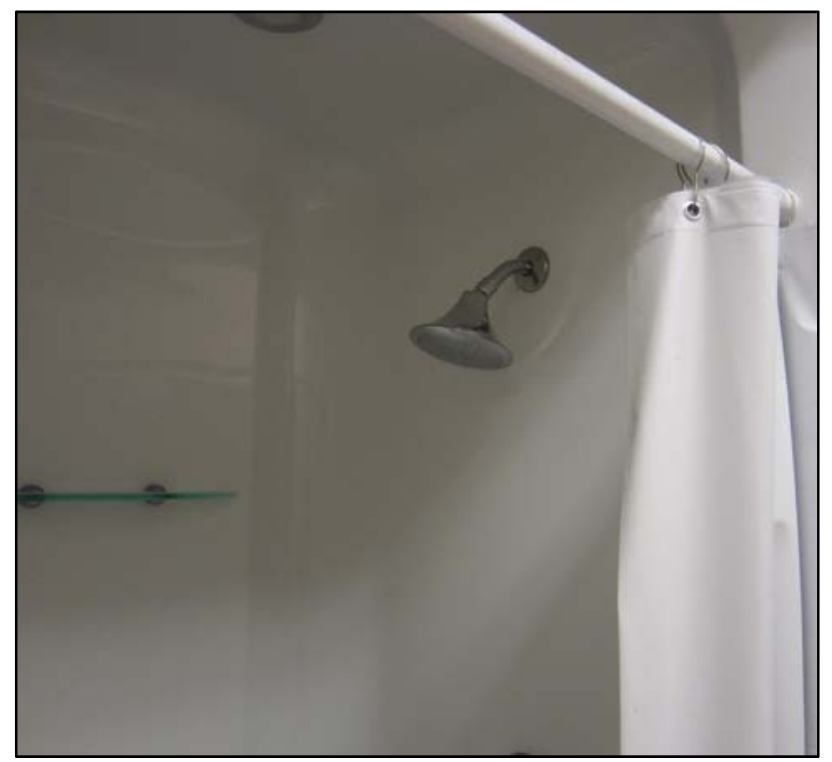

Figure 8. Showerheads Rated at 2. 5 gpm

Urinal efficiency varied from 0.3 gallons per flush (gpf) to 0.8 gpf based on unit ratings and time duration to flush. The higher efficiency units observed are in the men's locker room. A total of eight urinals were counted in RPL, three of which are present in the men's locker room. Water use from the five less efficient fixtures is estimated to be $25 \mathrm{Kgal}$ per year, while the water use from the locker room units is $9 \mathrm{Kgal}$ per year. Retrofits for the less efficient units with high efficiency 0.125 gpf units will save $21 \mathrm{Kgal}$ annually, or $\$ 90$ in water costs. The capital cost of this retrofit is $\$ 4,527$ resulting in a simple payback of 50 years (Table 10), which is not sufficient to make this feasible at this time. No projects to install more efficient urinals in the men's locker room were considered because they would achieve minimal savings.

Similar to bathroom faucets and urinals, the toilets at RPL varied in efficiency with 1. 0-gpf units observed in the locker rooms and $3.5 \mathrm{gpf}$ observed in the other restrooms. A total of 21 toilets were counted in the building with nine in the locker rooms. Water use from the thirteen less efficient units is estimated to be $128 \mathrm{Kgal}$ annually while use in the locker rooms is estimated at $35 \mathrm{Kgal}$ per year. No efficiency projects were considered for the locker rooms fixtures. Replacing the 13 less efficient toilets with 1. 28- gpf high-efficiency flushometer piston valve toilets is estimated to save $81 \mathrm{Kgal}$ of water

\footnotetext{
${ }^{15}$ WaterSense is a U.S. Environmental Protection Agency program that tests and recognizes products for water efficiency, similar to the ENERGY STAR program for energy efficiency.

$16 \%$ of the building population is about eight showers per day. Actual shower use may be higher or lower.
} 
annually for a cost savings of $\$ 346$. However, the economics are not attractive with a capital cost of the project at $\$ 7,431$ and a simple payback of 21 years (Table 10).

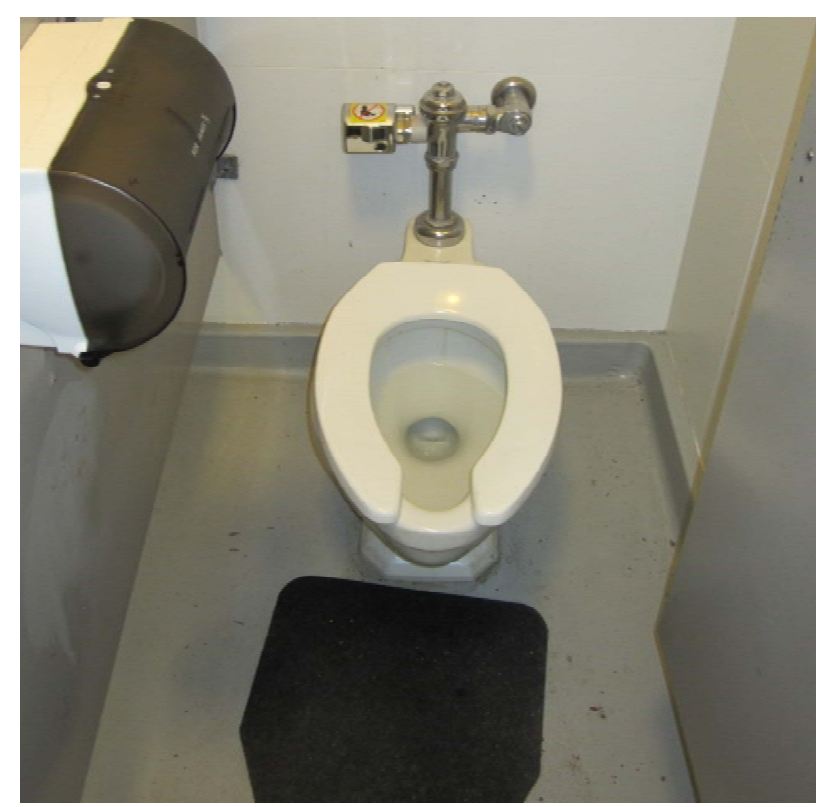

Figure 9. Toilet in Room 706

Table 10. Plumbing Retrofits

\begin{tabular}{lcccccc}
\hline \multicolumn{1}{c}{$\begin{array}{c}\text { Retrofit } \\
\text { Description }\end{array}$} & $\begin{array}{c}\text { First Year } \\
\text { Water } \\
\text { \# of } \\
\text { Units }\end{array}$ & $\begin{array}{c}\text { Savings } \\
\text { (Kgal) }\end{array}$ & $\begin{array}{c}\text { Heat } \\
\text { Energy } \\
\text { Savings } \\
(\text { MMBtu) }\end{array}$ & $\begin{array}{c}\text { First } \\
\text { Year } \\
\text { Cost } \\
\text { Savings }\end{array}$ & $\begin{array}{c}\text { Retrofit } \\
\text { Capital } \\
\text { Cost }\end{array}$ & $\begin{array}{c}\text { Simple } \\
\text { Payback } \\
(\mathrm{yr})\end{array}$ \\
\hline Toilet Replacement & 13 & 81 & - & $\$ 346$ & $\$ 7,431$ & 21.5 \\
Urinal Replacement & 5 & 21 & - & $\$ 90$ & $\$ 4,527$ & 50.1 \\
Faucet Replacement & 12 & 42 & 14 & $\$ 398$ & $\$ 188$ & 0.5 \\
$\begin{array}{l}\text { Showerhead } \\
\text { Replacement }\end{array}$ & 6 & 11 & 4 & $\$ 118$ & $\$ 167$ & 1.4 \\
\hline Totals & 36 & 155 & 18 & $\$ 952$ & $\$ 12,313$ & 12.9 \\
\hline
\end{tabular}

\subsection{Observations for Further Follow-Up}

In addition to the projects quantified previously, three areas were identified for further investigation. 


\subsubsection{Non-Administrative Plug Load Reduction}

The building may have other opportunities to optimize plug loads (reduce/turn off/seasonally and/or manage loads better etc. ) that we did not fully investigate(for example, the heat trace system, which has a manual toggle switch and a thermostat for each heat trace zone/circuit). If the existing system components are working correctly, the heat trace cables are de-energized when the temperature rises above the thermostat set point. The system can be manually shut down for the season by switching them off or locking the circuit breakers off. It was stated that this system was designed for a more automatic solution, but was not implemented.

It is apparent that the organization is well managed, and those involved in the operations and maintenance make every effort to manage energy consuming devices (plug loads/process loads), and that their due-diligence in this area will help sustain the already superb energy reductions seen over the last few years.

\subsubsection{Add Variable Frequency Drives (VFDs) for Smaller Pumps/Motors}

Some of the VFDs, such as those proposed for the four large exhaust fans (150 hp each) and all four large supply fans (60 hp each) were evaluated using the FEDs model, but some of the smaller models were not modeled in FEDs; yet should be considered to save additional energy while improving process control, and reducing mechanical stress (e. g. soft starts). In addition, since motors and VFDs need to be compatible, when replacing a motor, a VFD should be considered.

Centrifugal pumps run at a fixed speed yet could be improved if they had the means to modulate the speed; in other words, vary the flow to match the requirement. For instance, if operations call for $50 \%$ flow volume, and the flow can be modulated, then because of the affinity laws, only $12.5 \%$ of the power would be needed to run the system at $100 \%$ volume. The power requirements decrease faster than the reduction in volume; thus, at lower volumes or off-peak conditions, significant energy can be saved. Therefore, it is recommended to evaluate adding VFDs to all applications, even those with inlet vanes, but especially the following:

- The two preheat motors/pumps

- The two heat recovery motors/pumps

- The two reheat motors/pumps

\subsubsection{Renewable Energy}

Given the low marginal charge for electricity at RPL, solar photovoltaic, solar thermal and solar hot water were not identified as cost effective at this time. As the technology costs decrease the cost effectiveness of these systems should be re-evaluated. 


\subsection{Bibliography}

GSA. Condensing Boilers. Washington D. C. December 2012. http://www. gsa.

gov/portal/content/163495.

Office of the Deputy Prime Minister. Guide to the Condensing Boiler Installation Assessment Procedure for Dwellings. London. April 2005. https://www. gov.

je/SiteCollectionDocuments/Planning\%20and\%20building/ID\%20AssessmentGuidetoCondensingBoi lerInstallationinDwellings\%2020100910\%20mm. pdf

Phetteplace, Gary. 1995. Efficiency of Steam and Hot Water Heat Distribution Systems. Cold Regions Research and Engineering Laboratory. Hanover, New Hampshire. September 1995. http://www. crrel. usace. army. mil/library/crrelreports/CR95_18. pdf; downloaded 2/25/2014 

Appendix A Hourly Profile Analysis 



\section{Appendix A}

\section{Hourly Profile Analysis}

Power readings from PNNL's Decision Support for Operations and Maintenance (DSOM) building monitoring system were plotted in the Energy Charting and Metrics Tool (ECAM). The charts below represent 1 year: September 1, 2012 to August 31, 2013. This date range was chosen to coincide with the most accurate and recent utility data provided.

Figures A. 1 and A. 2 show the building occupants arrive between 5:15AM and 6:00AM on weekdays, and the building is unoccupied around 6:00 PM on weekdays. However, the base load on weekdays ( 750 and $760 \mathrm{kWh}$ ) is $90 \%$ of the peak consumption ( $\sim 830 \mathrm{kWh})$. This indicates that the majority of equipment is not setback or shutdown during any unoccupied periods.

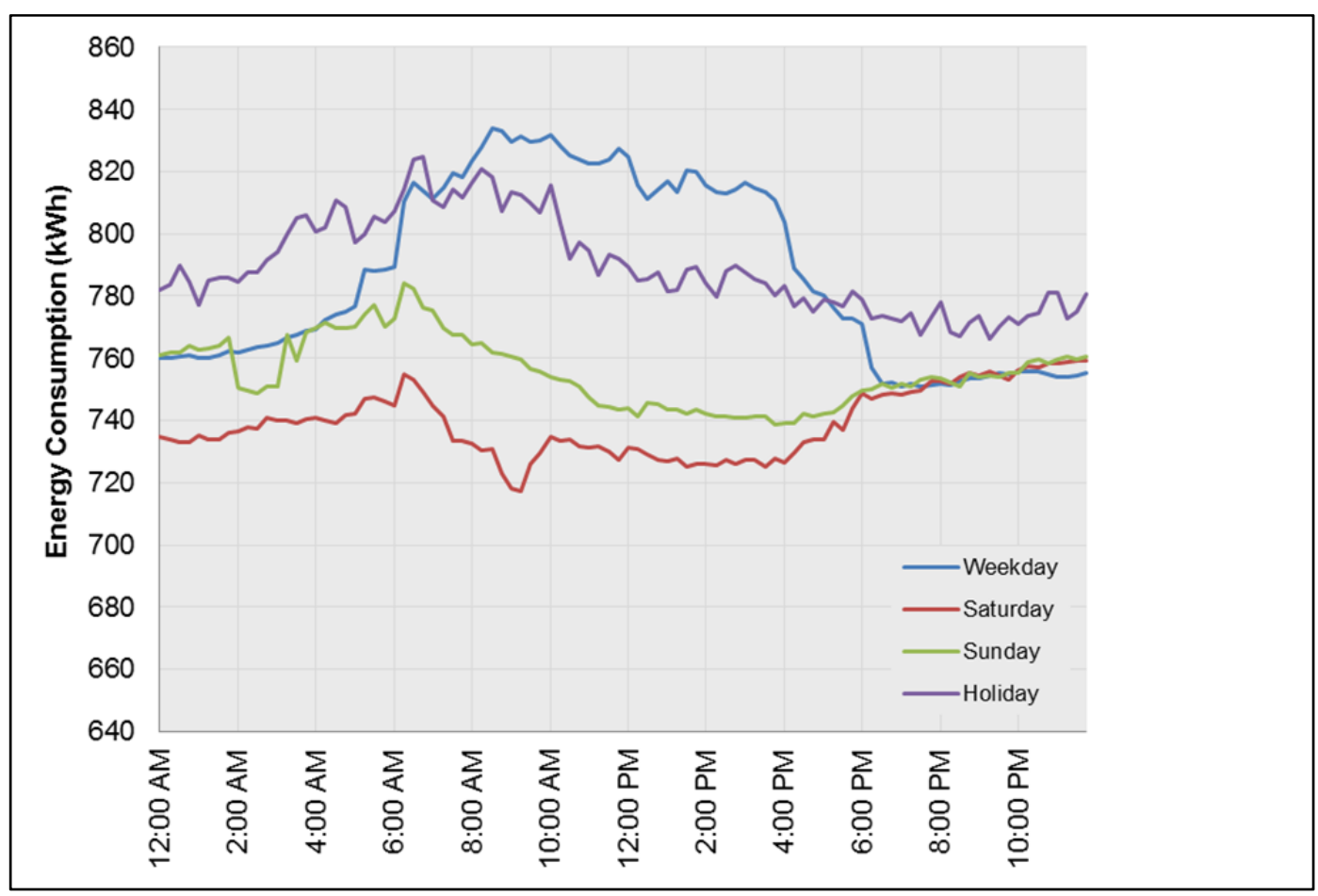

Figure A. 1. RPL Load Profile by Day Type 


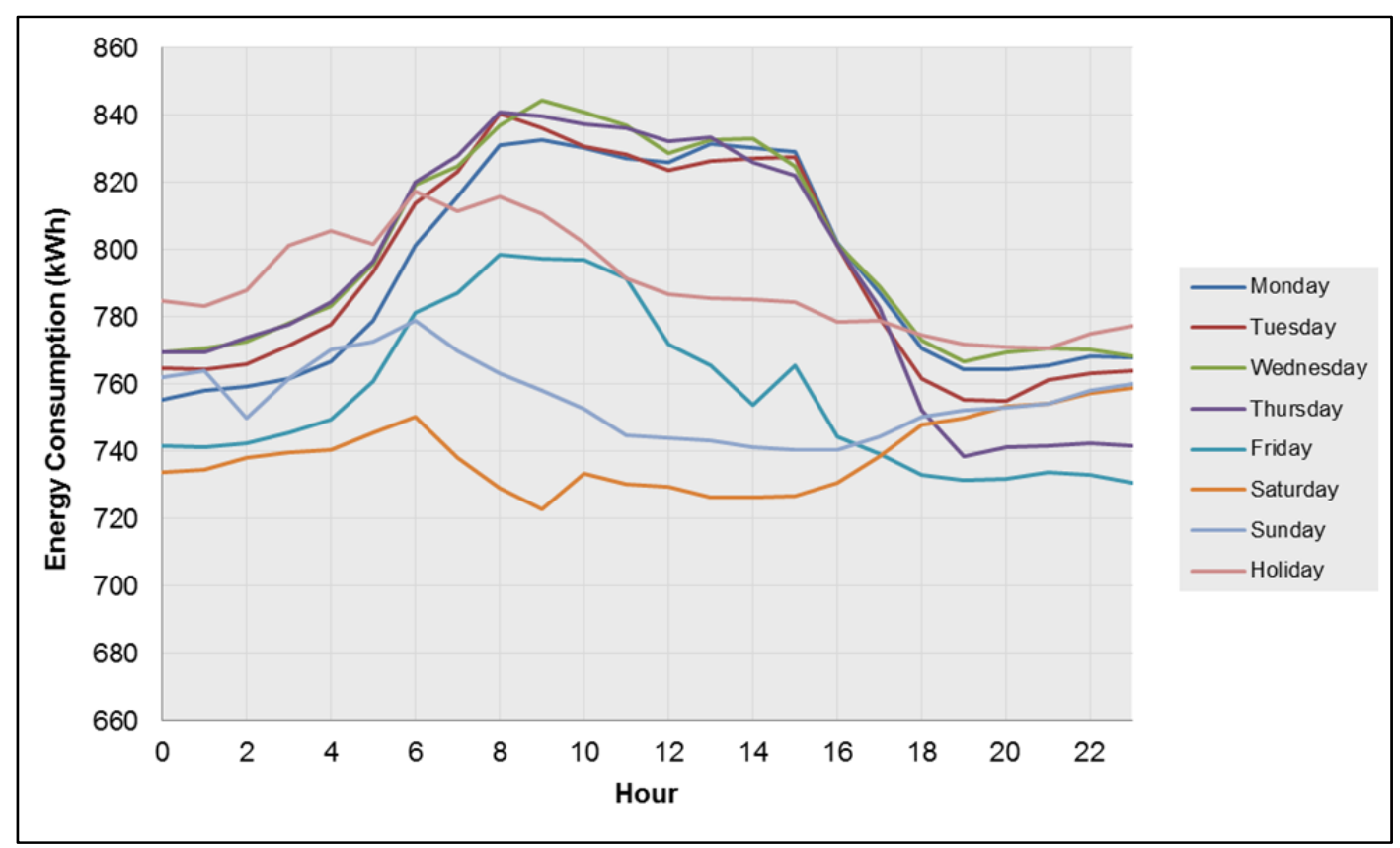

Figure A. 2. RPL Load Profile by Day of Week

Figures A. 3 and A. 4 demonstrate the building load as a function of outdoor air temperature for weekdays and weekends, respectively. There is a corresponding model fitting the data for each case, which will be discussed below. Both figures show the building being heated when the outdoor air temperature reaches $65^{\circ} \mathrm{F}$, indicating there is no temperature setback during the weekend. In addition, the data for both figures have a narrow variation, signifying the load characteristics of the building are consistent from day to day.

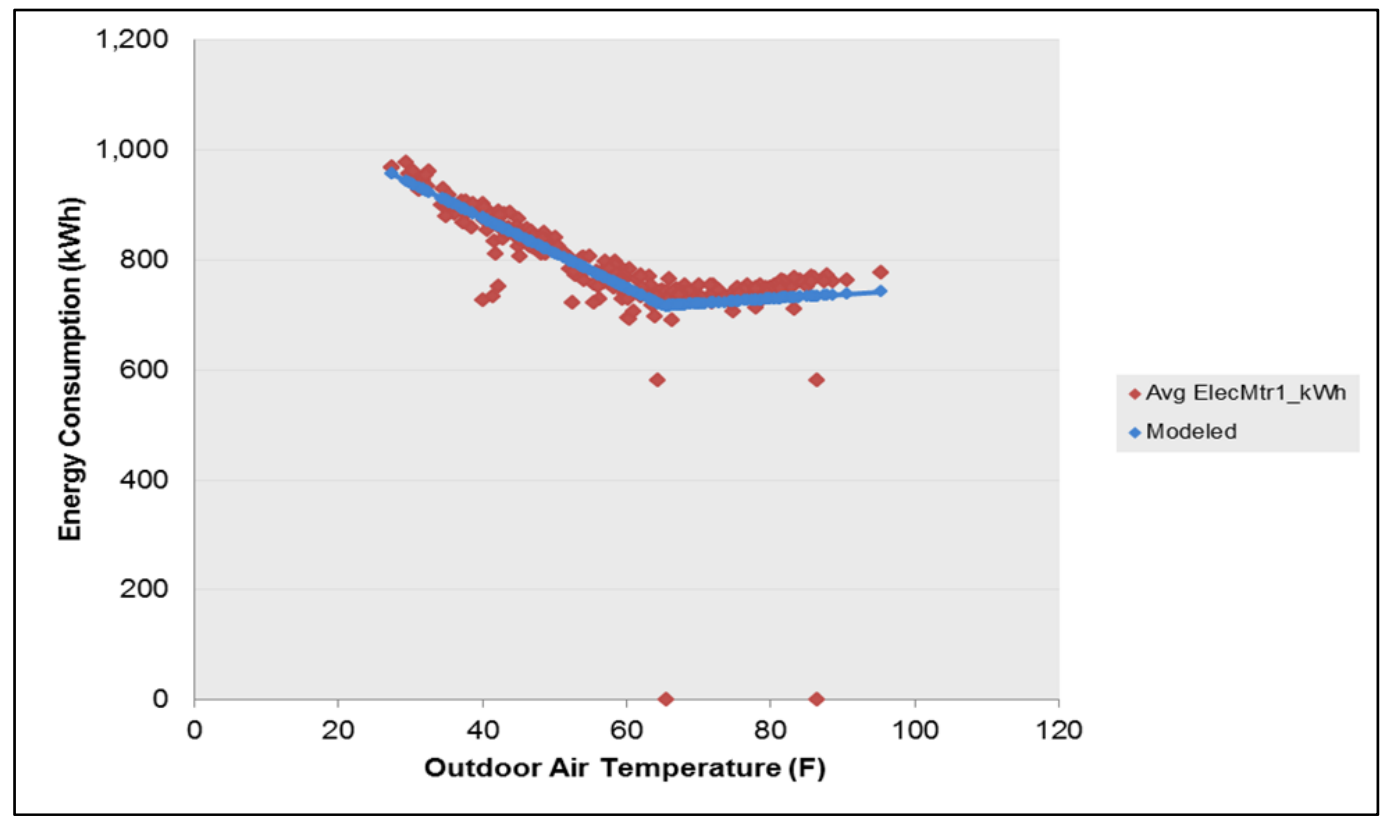

Figure A. 3. RPL Weekday Load Profile vs. Outdoor Air Temperature 


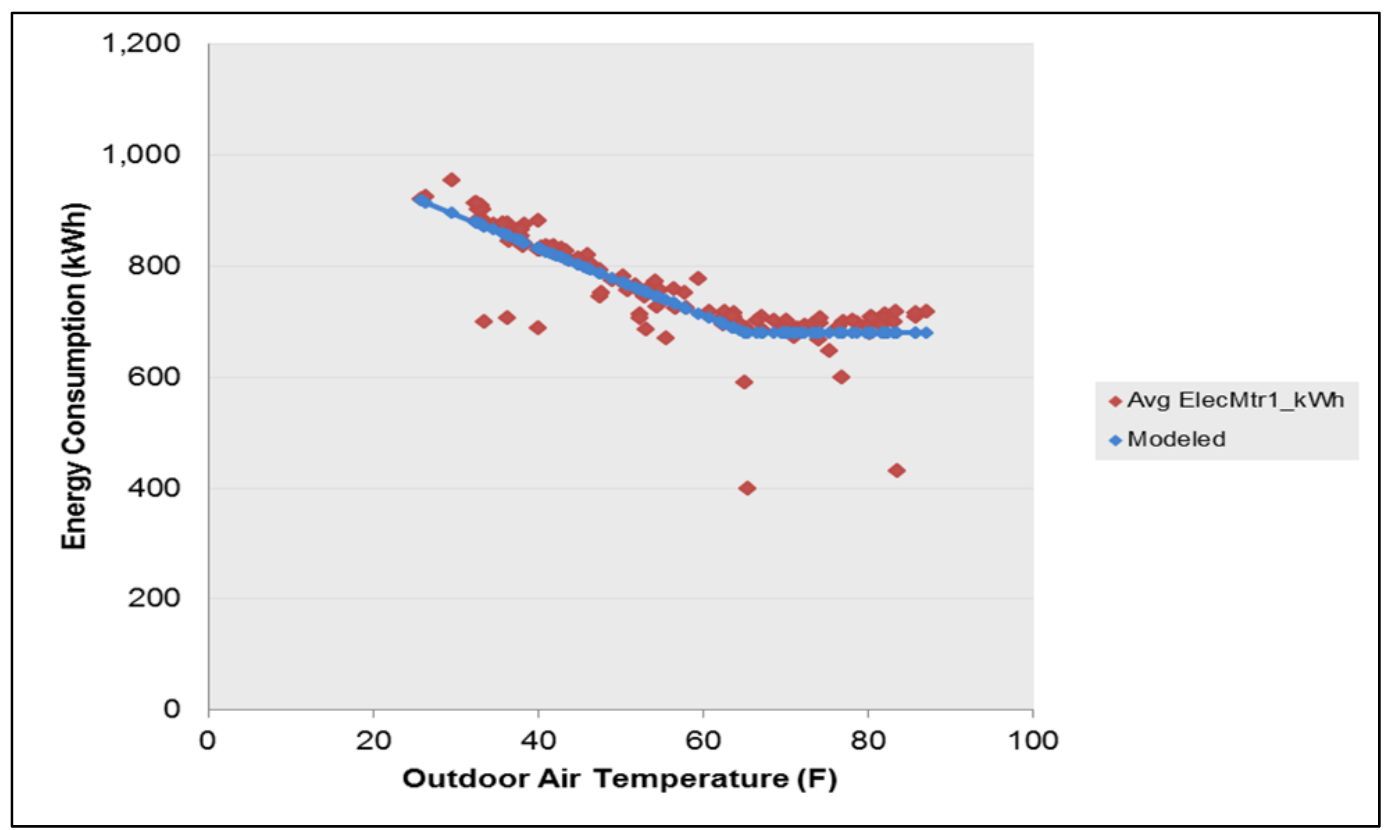

Figure A. 4. RPL Weekend Load Profile vs. Outdoor Air Temperature 



\section{Appendix B}

\section{FEDS Modeling, Calibration, and Outputs}





\section{Appendix B}

\section{FEDS Modeling, Calibration, and Outputs}

\section{B.1 Specialized FEDS Modeling Approach for RPL}

After all of the building characteristics were entered in the FEDS model, the model was run to infer various characteristics that are generally estimated using the model because many times measurements are not available (i. e. , infiltration, percent outdoor air fraction). The operating parameters were examined and additional information was gathered from F\&O staff to capture operating conditions in the RPL facility that differ significantly from the normal conditions that the model infers (i. e. , expects to be present) in a general laboratory/office building.

The first of these special operating conditions is that the ventilation exhaust air from the main building is used to assist in heating the ventilation supply air from the four large supply fans. Because the building brings in 100\% outdoor air, this input had to be adjusted in FEDS to $70 \%$ to account for the heat recovery. This adjustment helps FEDS calculate a more accurate natural gas and steam usage because not $100 \%$ of the air that is being conditioned is at outdoor air temperature.

The second special condition was the strategy used to capture the use of the boilers and the heating of the main building. The boilers are located in the boiler annex, on the southwest external side of the main building. These boilers provide steam to the air-handling units, where the steam is then converted to hot water to be used by the air handlers to heat approximately 93\% of the facility. A central plant scenario was then used in FEDS to account for any steam line losses and heat loss during the steam to hot water conversion. In addition, modeling the heating system as a central plant allowed for the ability to incorporate the substantial lack of condensate return.

\section{B.2 FEDS Calibration}

After information from the walkthrough audits and drawings is entered into FEDS, the model is calibrated to utility billing data (in this case, September 2012 through August 2013 electricity and natural gas consumption) so that the baseline case matches existing conditions in the buildings. If the baseline model is a reasonably close match with utility billing data, users can have a higher degree of confidence in the energy-saving retrofits generated by the model. Calibration results for Sept. 2012 through Aug. 2013 electricity consumption of RPL are shown in Table B. 1 and B. 2

Table B. 1. Building Electricity Calibration Annual Electricity Consumption (all values in kWh)

\begin{tabular}{lccc} 
FEDS Building Set & Actual & FEDS Calculation & \% Difference \\
\hline RPL & $7,313,573$ & $7,079,992$ & $3 \%$
\end{tabular}


The source of natural gas usage at RPL is in the boiler annex. Therefore, a single gas account serves the RPL facility. The FEDS building totals for natural gas are shown in Table B. 2.

Table B. 2. Natural Gas Calibration

Annual Natural Gas Consumption (all values in Therms)

\begin{tabular}{lccc}
\hline & & & \\
FEDS Building Set & Actual (Utility Bill) & FEDS Calculation & \% Difference \\
\hline RPL & 80,313 & 82,416 & $2 \%$
\end{tabular}

\section{B.3 FEDS Model Output}

The following tables (Table B. 3 and B. 4) show the output of the FEDS baseline model for energy use at RPL.

Table B. 3. Energy-Use Intensity

\begin{tabular}{lcccccc}
\hline & \multicolumn{3}{c}{ Electricity } & & \multicolumn{2}{c}{ Natural Gas } \\
\cline { 2 - 7 } & & $\begin{array}{c}\text { EUI } \\
(\mathrm{kWh} /\end{array}$ & $\begin{array}{c}\text { EUI } \\
(\mathrm{MMBtu} /\end{array}$ & & $\begin{array}{c}\text { EUI } \\
(\text { therms/ }\end{array}$ & $\begin{array}{c}\text { EUI } \\
(\mathrm{MMBtu} /\end{array}$ \\
FEDS Building Set & $\mathrm{kWh}$ & $\left.1,000 \mathrm{ft}^{2}\right)$ & $\left.1,000 \mathrm{ft}^{2}\right)$ & Therms & $\left.1,000 \mathrm{ft}^{2}\right)$ & $\left.1,000 \mathrm{ft}^{2}\right)$ \\
\hline RPL & $3,982,672$ & 27,501 & 94 & 101,978 & 704 & 70
\end{tabular}

Table B. 4. Energy Consumption by End-Use

\begin{tabular}{lcccc}
\hline \multirow{2}{*}{ FEDS Building Set } & HVAC & Lighting & Motors/Misc & Hot Water \\
\cline { 2 - 5 } First Floor and Basement & $2,333,435$ & 510,850 & 712,255 & 5,489 \\
Second Floor & 19,345 & 50,871 & 52,379 & 1,542 \\
\hline$\%$ of Total & $64 \%$ & $15 \%$ & $21 \%$ & $0.2 \%$ \\
\hline
\end{tabular}


Appendix C

\section{Audit Forms Used During Walkthroughs}





\begin{tabular}{|c|c|c|c|c|c|c|c|}
\hline \multicolumn{4}{|l|}{ Site Name } & \multicolumn{4}{|c|}{ Building Number/Name } \\
\hline Auditor Name & & & & \multicolumn{4}{|c|}{ Date of Audit } \\
\hline \multicolumn{8}{|l|}{$\begin{array}{l}\text { BUILDING ENVELOPE } \\
\text { ROOF }\end{array}$} \\
\hline \multicolumn{2}{|l|}{$\begin{array}{l}\text { Roof Type: } \\
\text { Built- up } \\
\text { Pre-Engineered Metal } \\
\text { Shingles/Shakes }\end{array}$} & \multicolumn{3}{|c|}{$\begin{array}{l}\text { Deck Type (built-up) } \\
\text { Wood } \\
\text { Concrete } \\
\text { Metal }\end{array}$} & & \multicolumn{2}{|c|}{$\begin{array}{l}\text { Suspended Ceiling: } \\
\text { Yes No } \\
\text { Roof/Ceiling Insulation } \\
\text { Yes No Thickness: }\end{array}$} \\
\hline \multicolumn{8}{|l|}{ FLOOR } \\
\hline \multicolumn{2}{|l|}{$\begin{array}{l}\text { Floor Type: } \\
\text { Slab on Grade } \\
\text { Crawlspace/Basement }\end{array}$} & \multicolumn{3}{|c|}{$\begin{array}{l}\text { Ground Floor Carpet: } \\
\text { Yes No }\end{array}$} & & \multicolumn{2}{|c|}{$\begin{array}{l}\text { Floor Insulation: } \\
\text { Yes No Thickness: }\end{array}$} \\
\hline \multicolumn{8}{|l|}{ WALLS } \\
\hline \multicolumn{2}{|l|}{$\begin{array}{l}\text { Exterior Wall Type: } \\
\text { Wood Siding } \\
\text { Masonry Façade } \\
\text { Pre-Engineered Metal } \\
\end{array}$} & \multicolumn{4}{|c|}{$\begin{array}{l}\text { Frame Type: } \\
\text { Wood Frame } \\
\text { Masonry Frame } \\
\text { Steel Frame }\end{array}$} & \multicolumn{2}{|c|}{$\begin{array}{l}\text { Wall Insulation: } \\
\text { Yes No Thickness: }\end{array}$} \\
\hline \multicolumn{8}{|l|}{ WINDOWS } \\
\hline \% Wall Area Glass: & \multicolumn{2}{|c|}{$\begin{array}{c}\text { \# of Panes: } \\
1 \\
2 \\
3\end{array}$} & \multicolumn{2}{|c|}{$\begin{array}{c}\text { Frame Type: } \\
\text { Wood/Vinyl } \\
\text { Metal } \\
\text { Thermal Break Metal }\end{array}$} & \multicolumn{2}{|c|}{$\begin{array}{l}\text { Window Coverings: } \\
\text { Tinting } \\
\text { Film } \\
\text { Shades/Blinds/Curtains } \\
\text { Gas Filled } \\
\end{array}$} & $\begin{array}{l}\text { Film Type: } \\
\text { Reflective } \\
\text { Low-e } \\
\text { Super Low-e }\end{array}$ \\
\hline \multicolumn{8}{|c|}{ Is weather stripping/caulking worn, damaged, or missing? } \\
\hline \multirow[t]{3}{*}{ Location: } & \multirow{3}{*}{\multicolumn{2}{|c|}{ Description: }} & \multicolumn{3}{|c|}{ Count (1st floor/upper floors): } & Size: & Condition: \\
\hline & & & \multicolumn{3}{|c|}{ / } & & \\
\hline & & & \multicolumn{3}{|c|}{ I } & & \\
\hline \multicolumn{8}{|l|}{ INTERIOR WORKSPACE } \\
\hline \multicolumn{8}{|l|}{ USE AREA DEFINITION } \\
\hline \multicolumn{2}{|l|}{ Use Area Description: } & \multicolumn{2}{|c|}{$\%$ of Building: } & \multicolumn{2}{|c|}{ \# of Floors: } & $\begin{array}{l}\text { Floor to Ceiling } \\
\text { Height (ft.): }\end{array}$ & $\begin{array}{l}\text { Floor to Floor } \\
\text { Height (ft.): }\end{array}$ \\
\hline 1: & & & & & & & \\
\hline 2: & & & & & & & \\
\hline OCCUPANCY & & & & & & & \\
\hline & & & Use & Area 1 & & Use & Area 2 \\
\hline & & & kday & Wee & rend & Weekday & Weekend \\
\hline Start & & & & & & & \\
\hline End & & & & & & & \\
\hline \# Occupants (Occupied) & & & & & & & \\
\hline \# Occupants (Unoccupied) & & & & & & & \\
\hline Seasonal variations in occup & ncy & & & & & & \\
\hline Estimated \% Men/Women: & & Men: & & Women: & & Men: & Women: \\
\hline
\end{tabular}




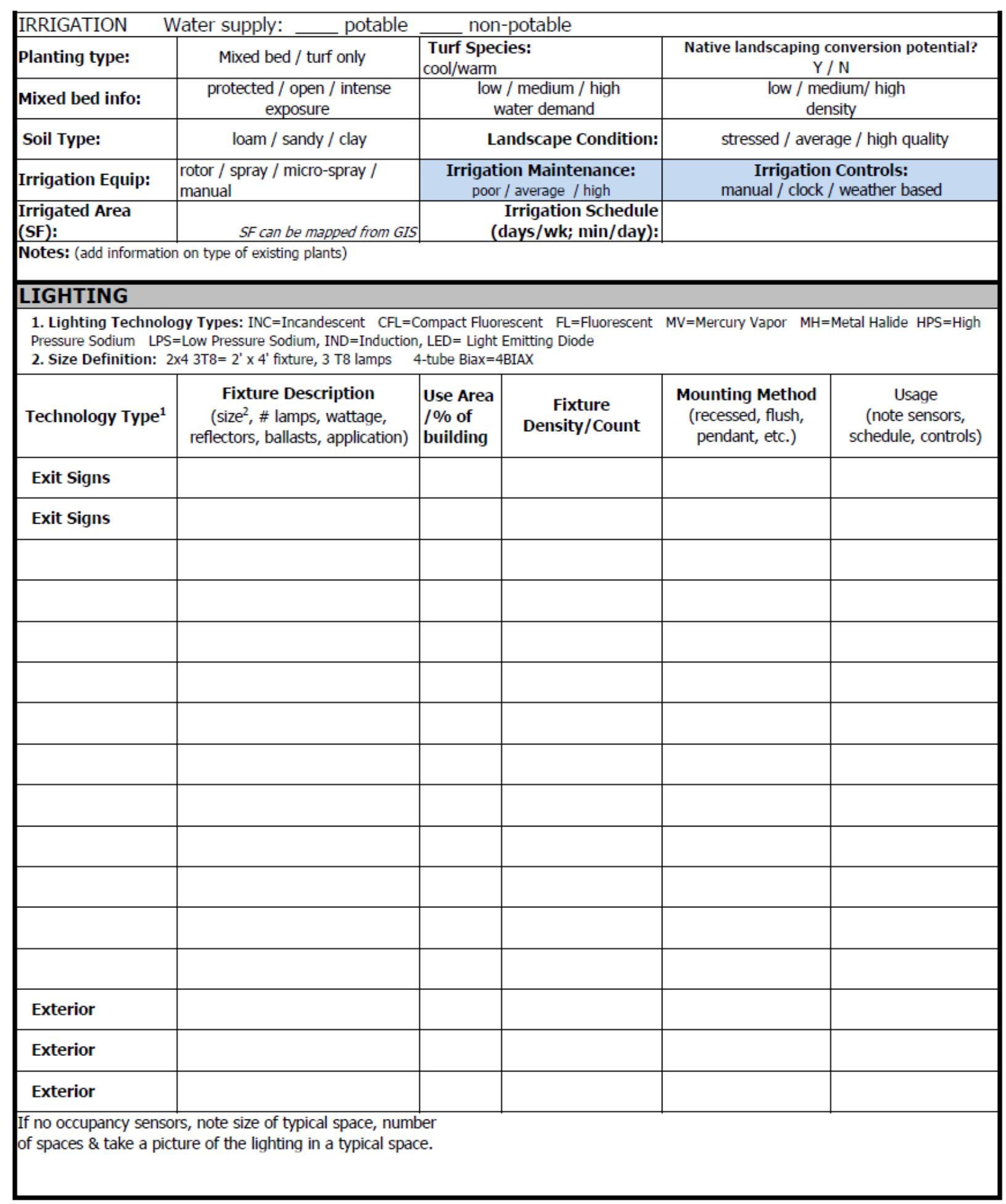




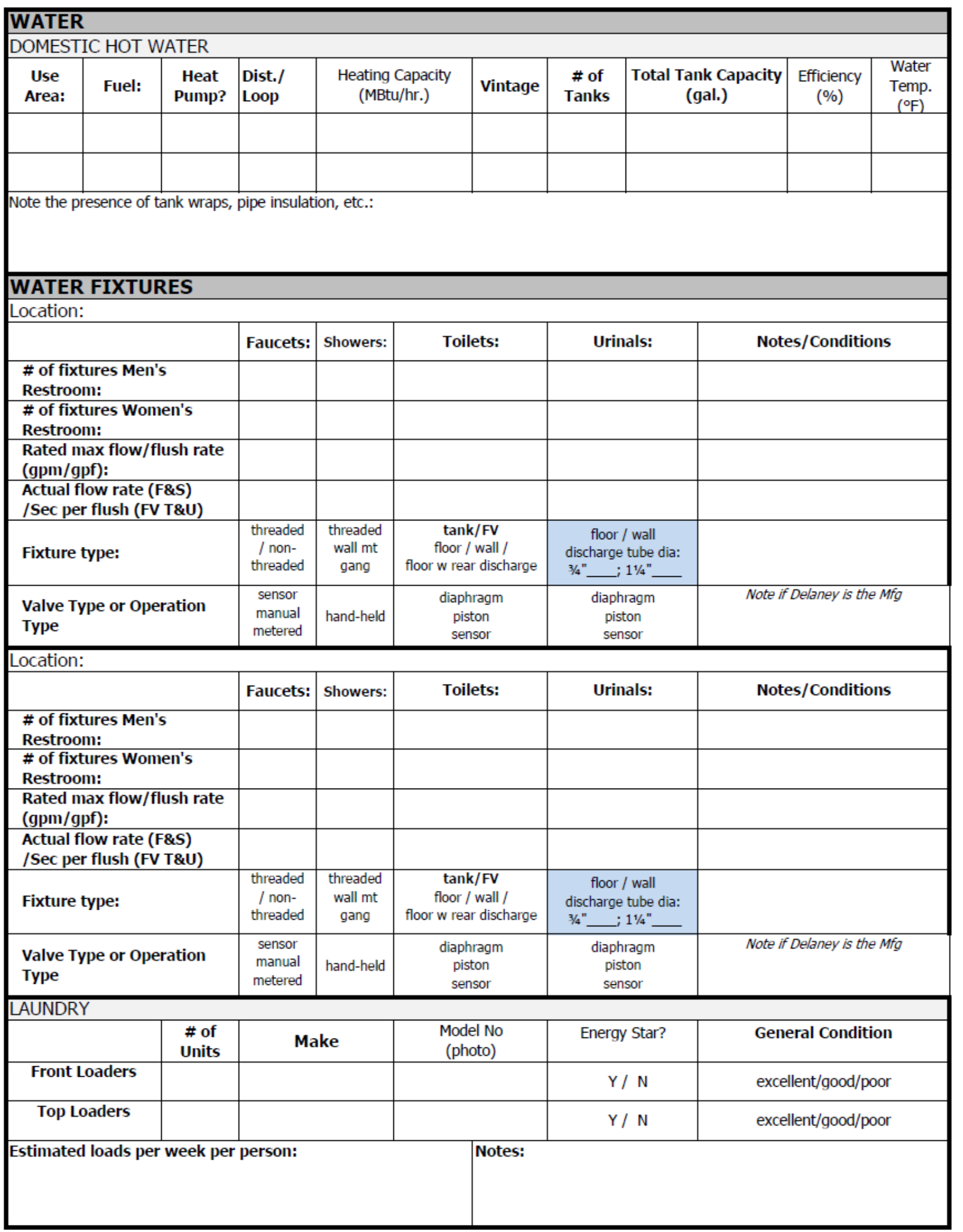




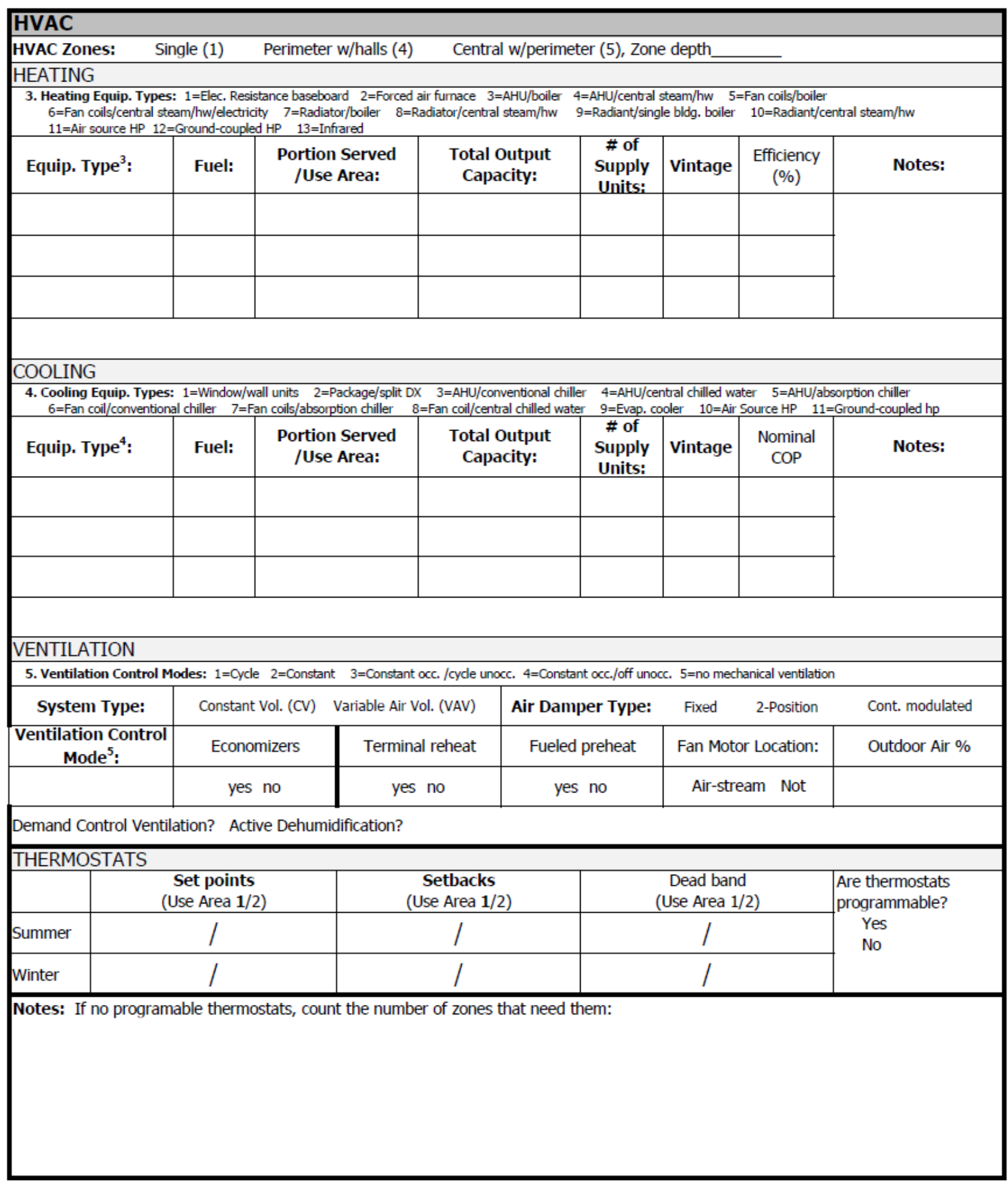




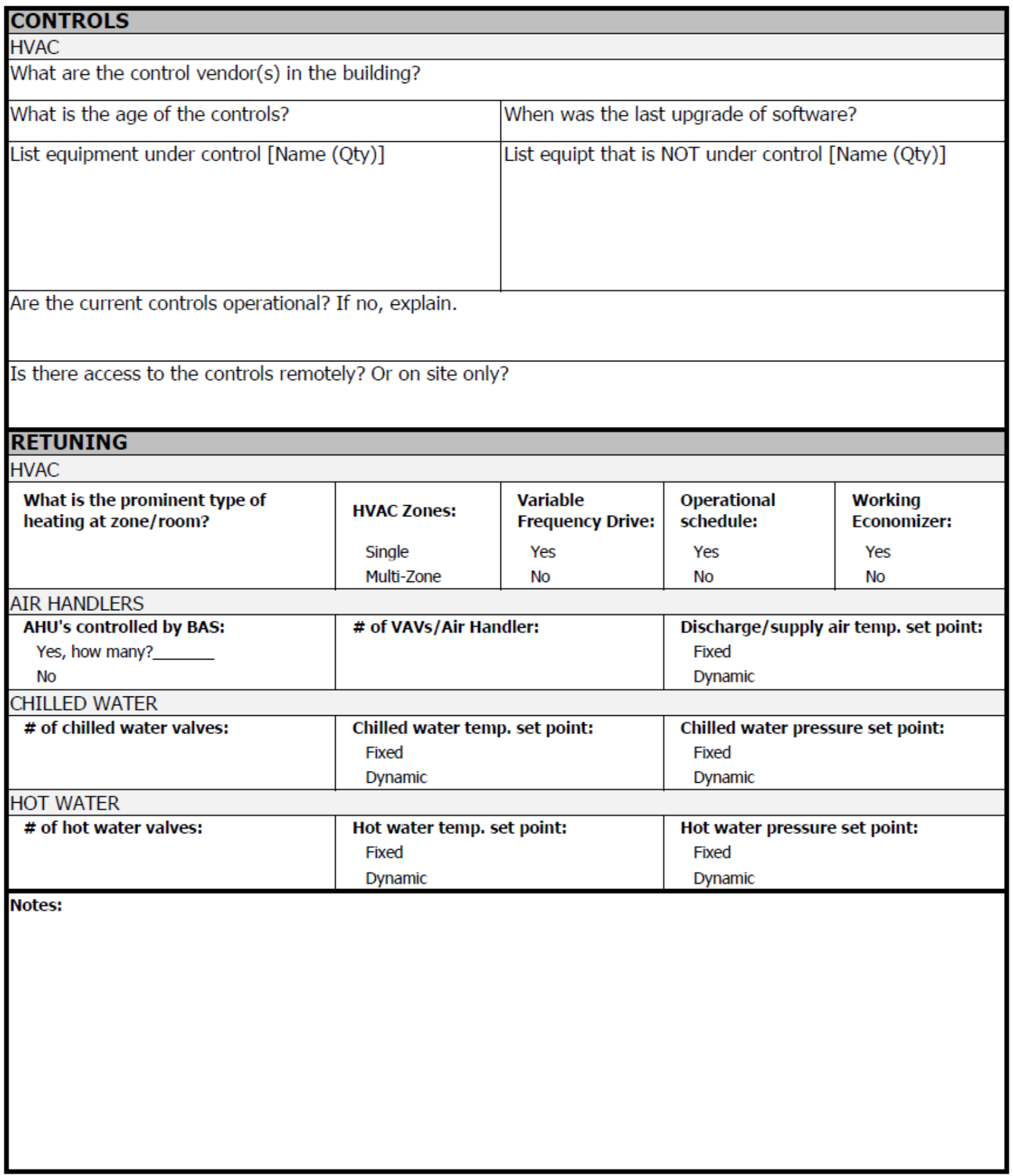




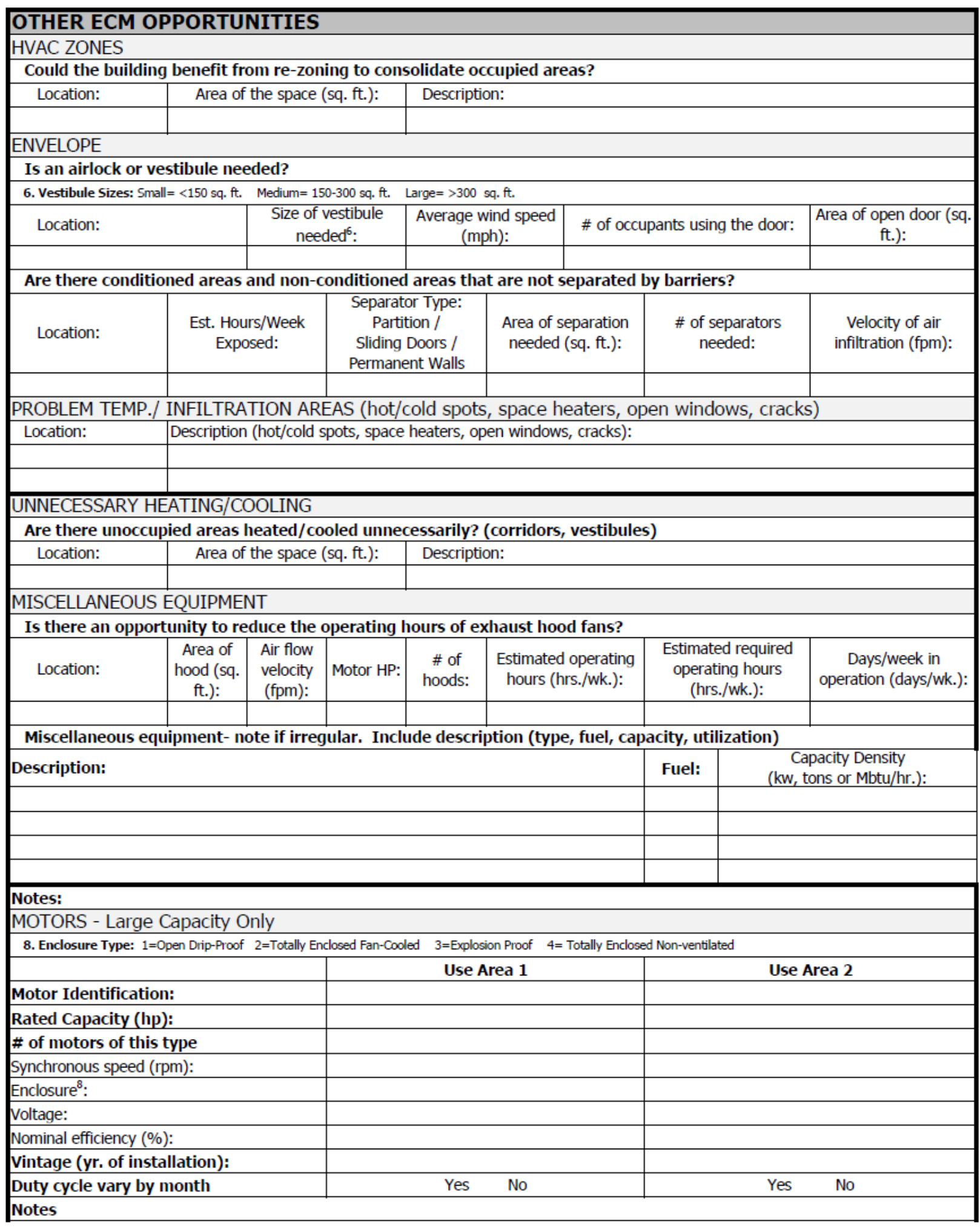




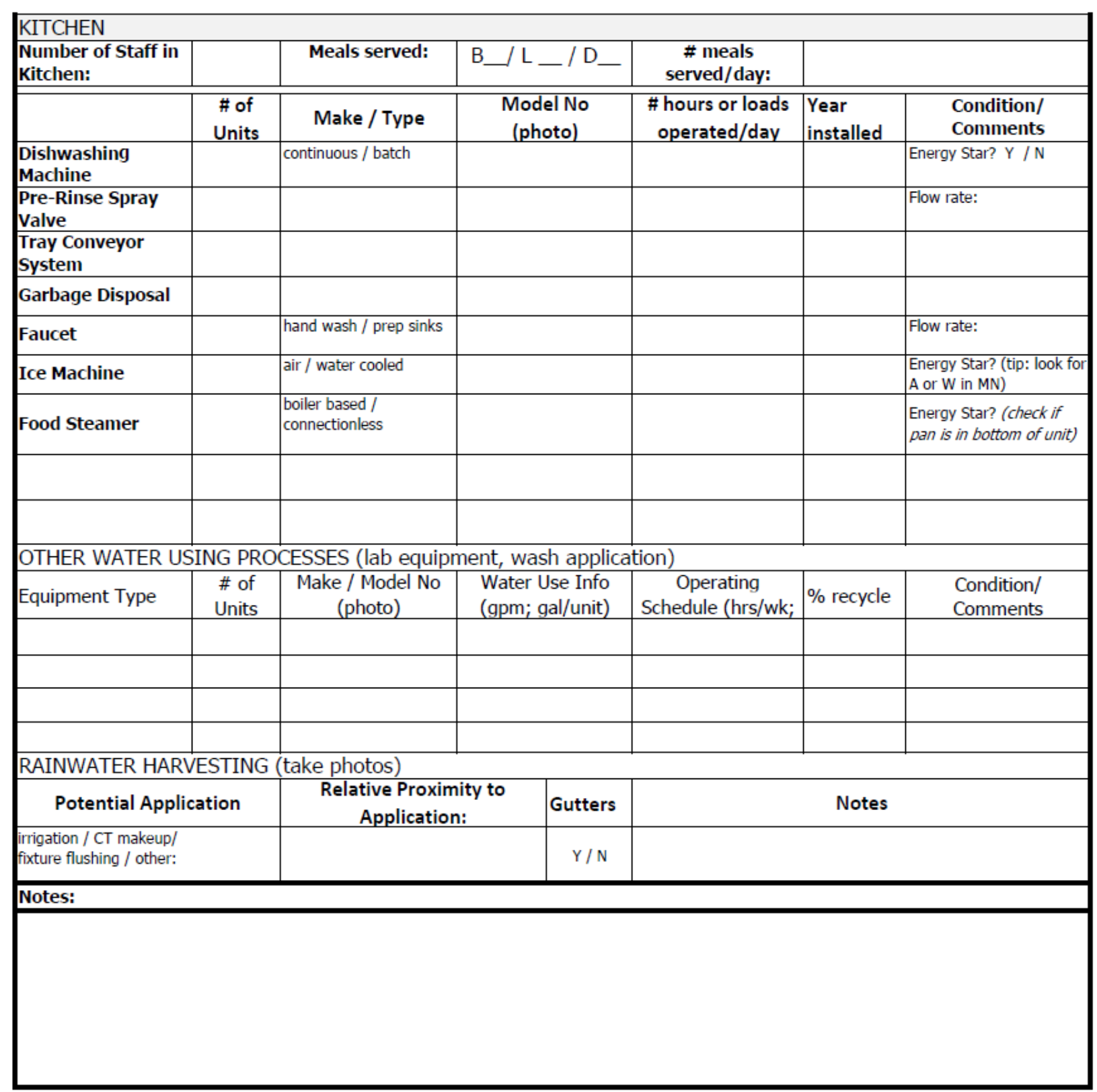



Appendix D

\section{Domestic Fixture Water Use Estimate}





\section{Appendix D}

\section{Domestic Fixture Water Use Estimate}

\section{D.1 General Information}

RPL assigned population: 154

Assume 67\% men, 33\% women (based on observed population dynamics during the walkthrough audit): 103 men, 51 women

\section{D.2 Domestic Fixture Estimating Tool Inputs}

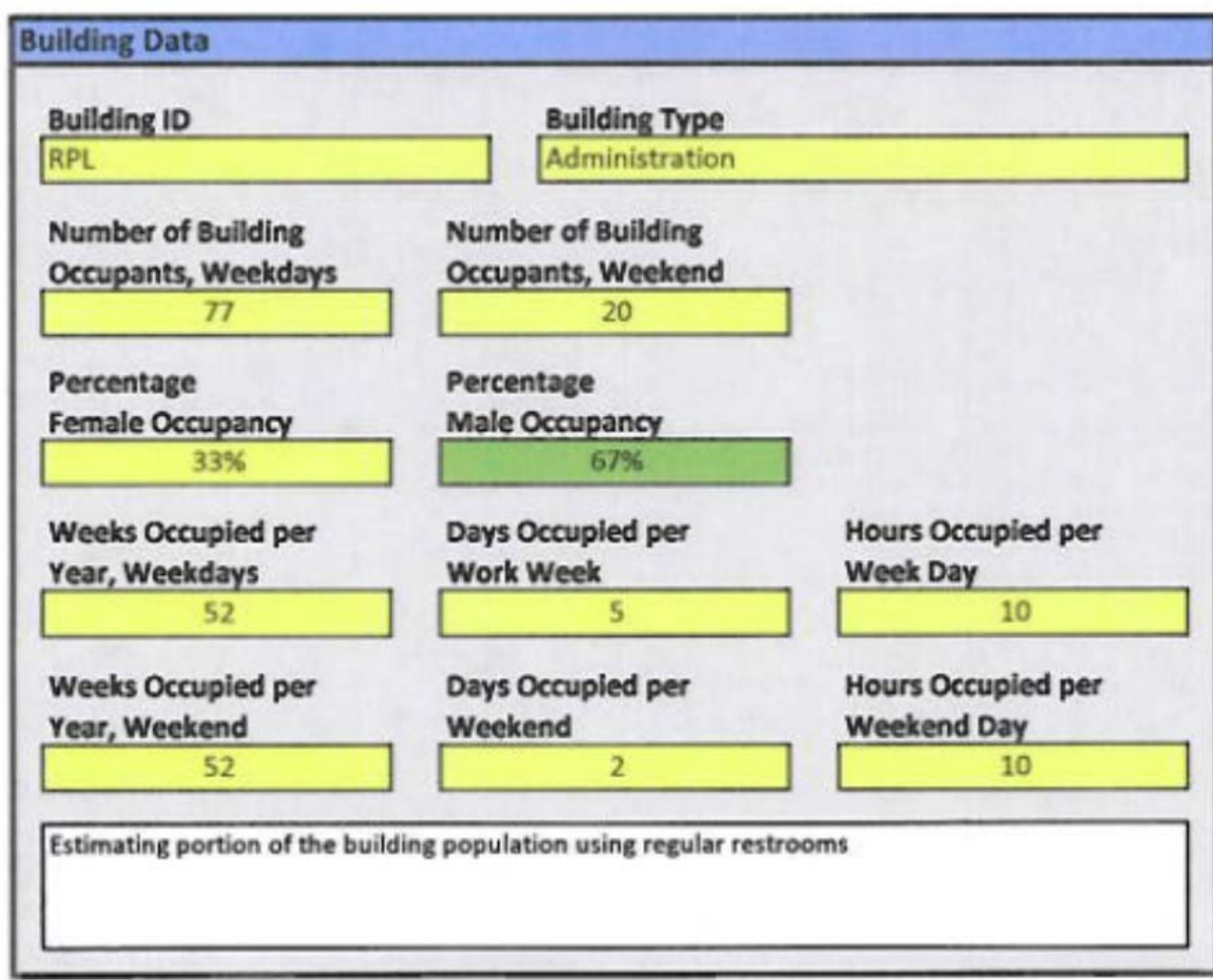




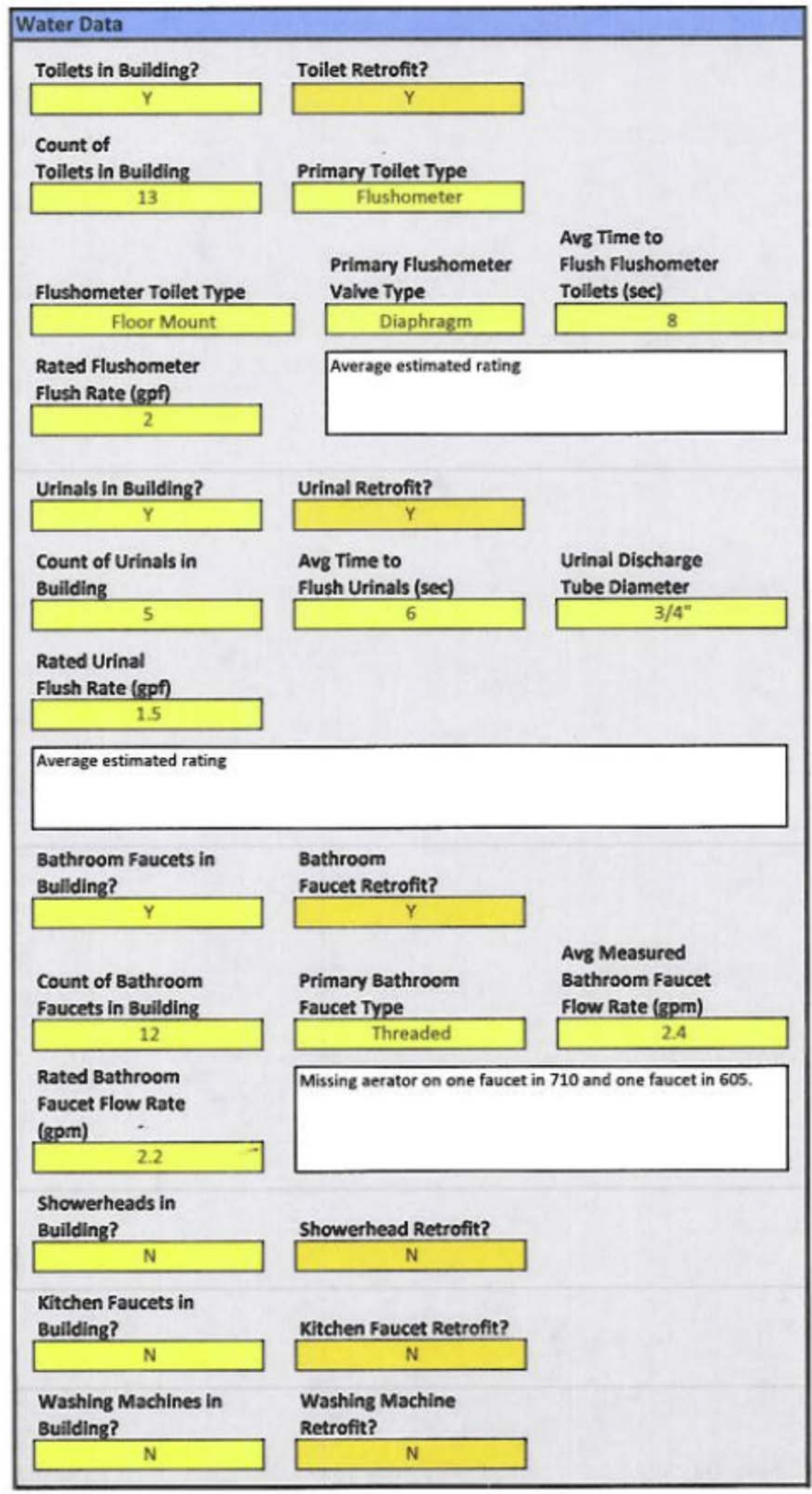




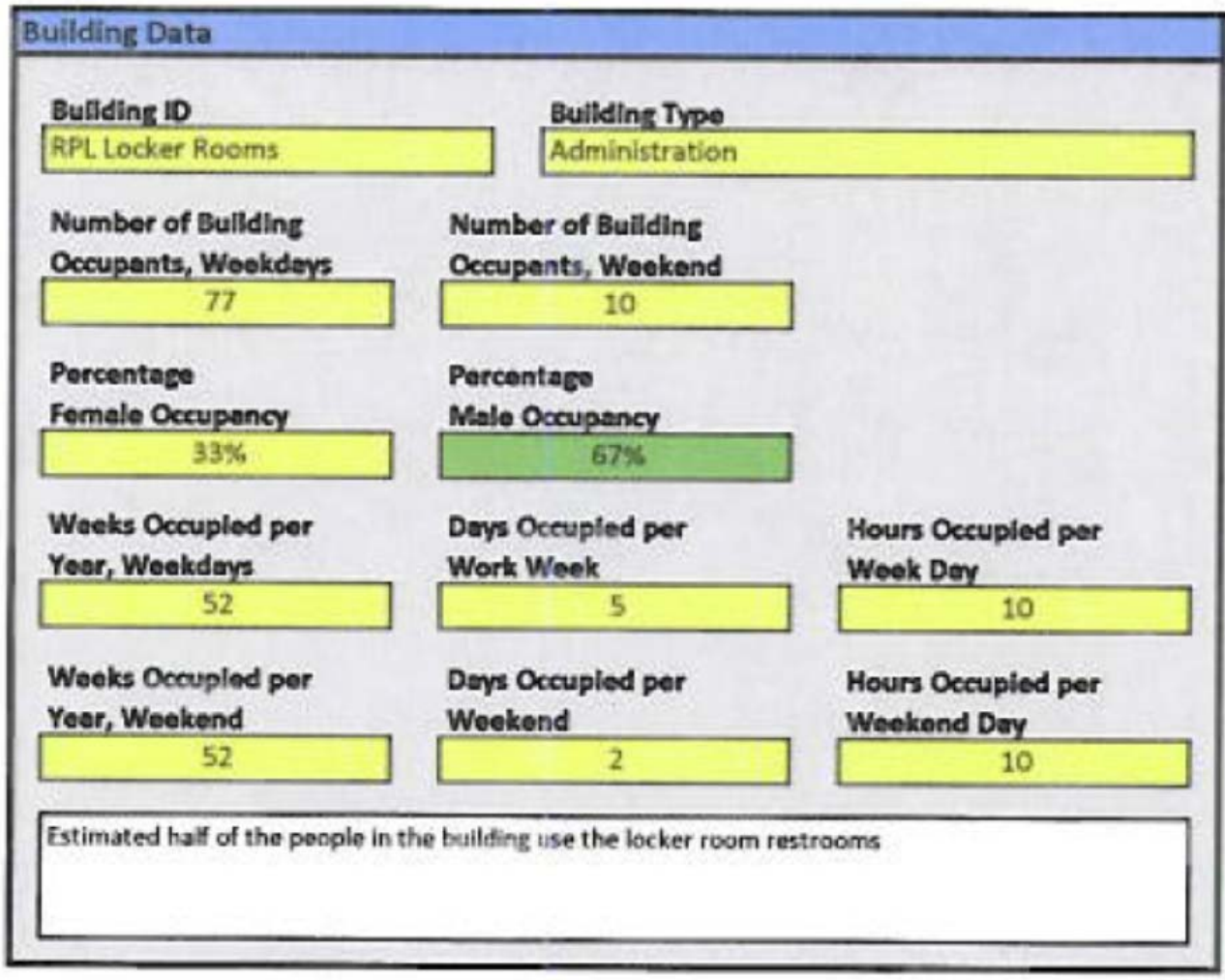




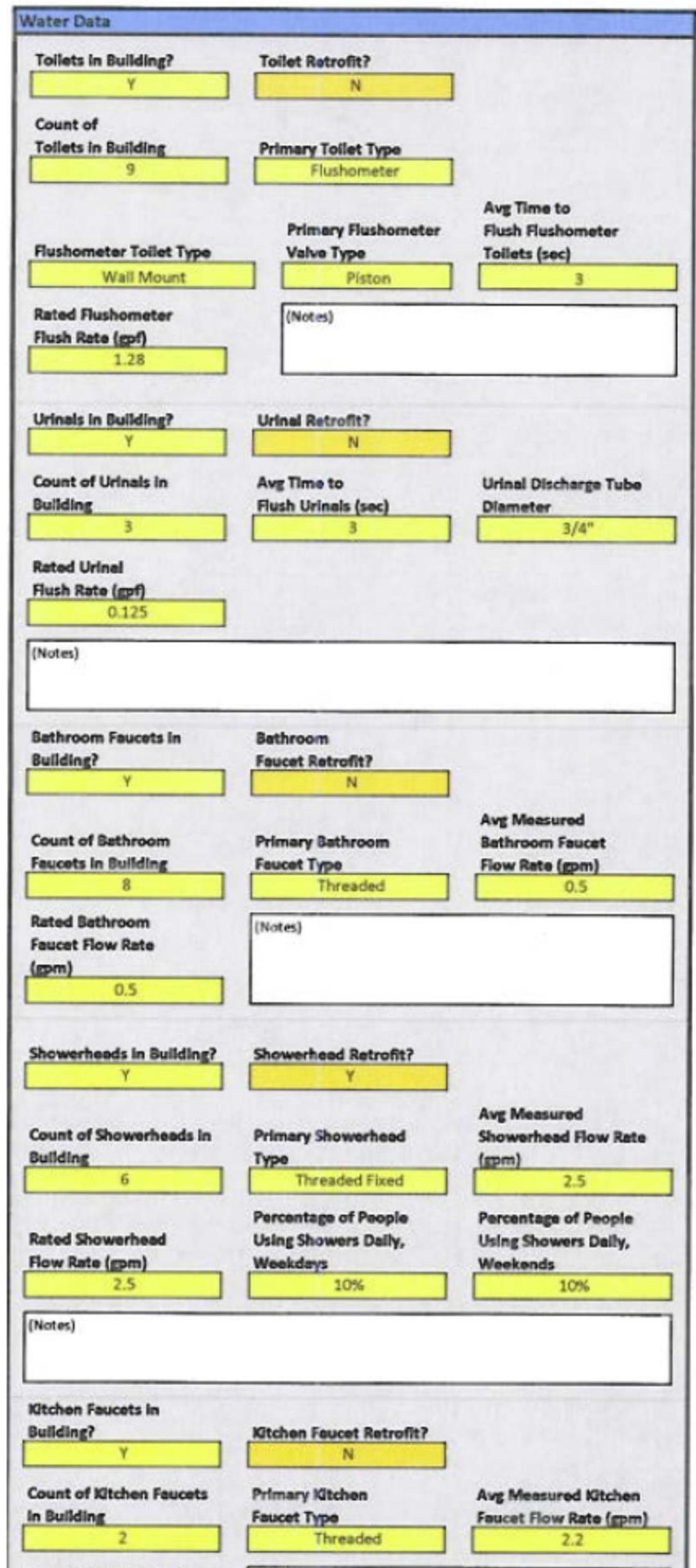




\section{D.3 Domestic Fixture Estimating Tool Results}

\begin{tabular}{|c|c|c|c|c|c|c|c|c|c|c|c|c|c|}
\hline \multirow[b]{3}{*}{ Current Fixture } & & & & \multirow{2}{*}{\begin{tabular}{|c|}
$\begin{array}{c}\text { Total Estimated } \\
\text { Usage (gpy) }\end{array}$ \\
292842.77 \\
\end{tabular}} & & & \multirow{2}{*}{\begin{tabular}{|c|}
$\begin{array}{c}\text { Total Retrofit } \\
\text { Usage (gpy) }\end{array}$ \\
78206.28
\end{tabular}} & \multirow{2}{*}{$\begin{array}{c}\begin{array}{c}\text { Total Water } \\
\text { Savings (gpy) }\end{array} \\
155249.02\end{array}$} & $\begin{array}{l}\text { Install cost } \\
\text { (\$) }\end{array}$ & \begin{tabular}{|c|} 
Heating Energy \\
Savings \\
(MMBTU)
\end{tabular} & \multirow[b]{3}{*}{$\begin{array}{c}\text { Water Cost } \\
\text { Savings (\$/year) }\end{array}$} & \multirow[b]{3}{*}{$\begin{array}{c}\text { Energy Cost } \\
\text { Savings ( } \$ \text { / / year) }\end{array}$} & \multirow[b]{3}{*}{$\begin{array}{c}\text { Simple Paybacl } \\
\text { (years) }\end{array}$} \\
\hline & & & & & & & & & 12,314 & 17.93 & & & \\
\hline & Fixture Type & $\begin{array}{c}\text { Total } \\
\text { Number of } \\
\text { Fixtures }\end{array}$ & $\begin{array}{l}\text { Existing Water Rate } \\
\text { (gpm, gpf, } \\
\text { gal/cycle/cuftt) }\end{array}$ & \begin{tabular}{|c|} 
Estimated Usage \\
(gpy)
\end{tabular} & New Type of Fixture to be Installed & $\begin{array}{l}\text { New Water } \\
\text { Rate } \\
\text { (gpm, gpf, } \\
\text { or gal/load) }\end{array}$ & $\begin{array}{c}\text { Retrofit Usage } \\
\text { (gpy) }\end{array}$ & $\begin{array}{c}\text { Water Savings } \\
\text { (gpy) }\end{array}$ & $\begin{array}{l}\text { Capital cost } \\
(\$)\end{array}$ & $\begin{array}{l}\text { Heating Energy } \\
\text { Savings } \\
\text { (MMBtu) }\end{array}$ & & & \\
\hline$=$ & 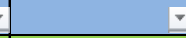 & & & 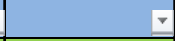 & & & 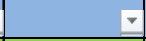 & $\nabla$ & $\nabla$ & -1 & - & -1 & $=$ \\
\hline Toilet & \begin{tabular}{|l|}
$\begin{array}{l}\text { Diaphragm-valve, } \\
\text { Floor Mount }\end{array}$ \\
\end{tabular} & 13 & 3.5 & 127,655 & HET flushometer piston valve and bowl & 1.28 & 46,685 & 80,970 & 7,431 & 0.00 & 346.06 & $\$$ & 21.47 \\
\hline Urinal & Urinal & 5 & 0.8 & 24,856 & HEU - pint piston flushometer & 0.13 & 3,728 & 21,128 & 4,527 & 0.00 & 90.30 & $\$$ & 50.14 \\
\hline Bathroom Faucet & Threaded & 12 & 2.4 & 53,040 & HE public lavatory faucet & 0.50 & 11,050 & 41,990 & 188 & 13.59 & 179.47 & 219.08 & 0.47 \\
\hline Toilet & $\begin{array}{l}\begin{array}{l}\text { Piston-valve, Wall } \\
\text { Mount }\end{array} \\
\end{array}$ & 9 & 1.0 & 34,746 & No retrofit. & & & & & & & & \\
\hline Urinal & Urinal & 3 & 0.3 & 9,478 & No retrofit. & & & & & & & & \\
\hline Bathroom Faucet & Threaded & 8 & 0.5 & 10,530 & No retrofit. & & & & & & & & \\
\hline Showerhead & Threaded Fixed & 6 & 2.5 & 27,905 & HE Watersense showerhead & 1.50 & 16,743 & 11,162 & 167 & 4.34 & 47.71 & 69.88 & 1.42 \\
\hline Kitchen Faucet & Threaded & 2 & 2.2 & 4,633 & No retrofit. & & & & & & & & \\
\hline
\end{tabular}





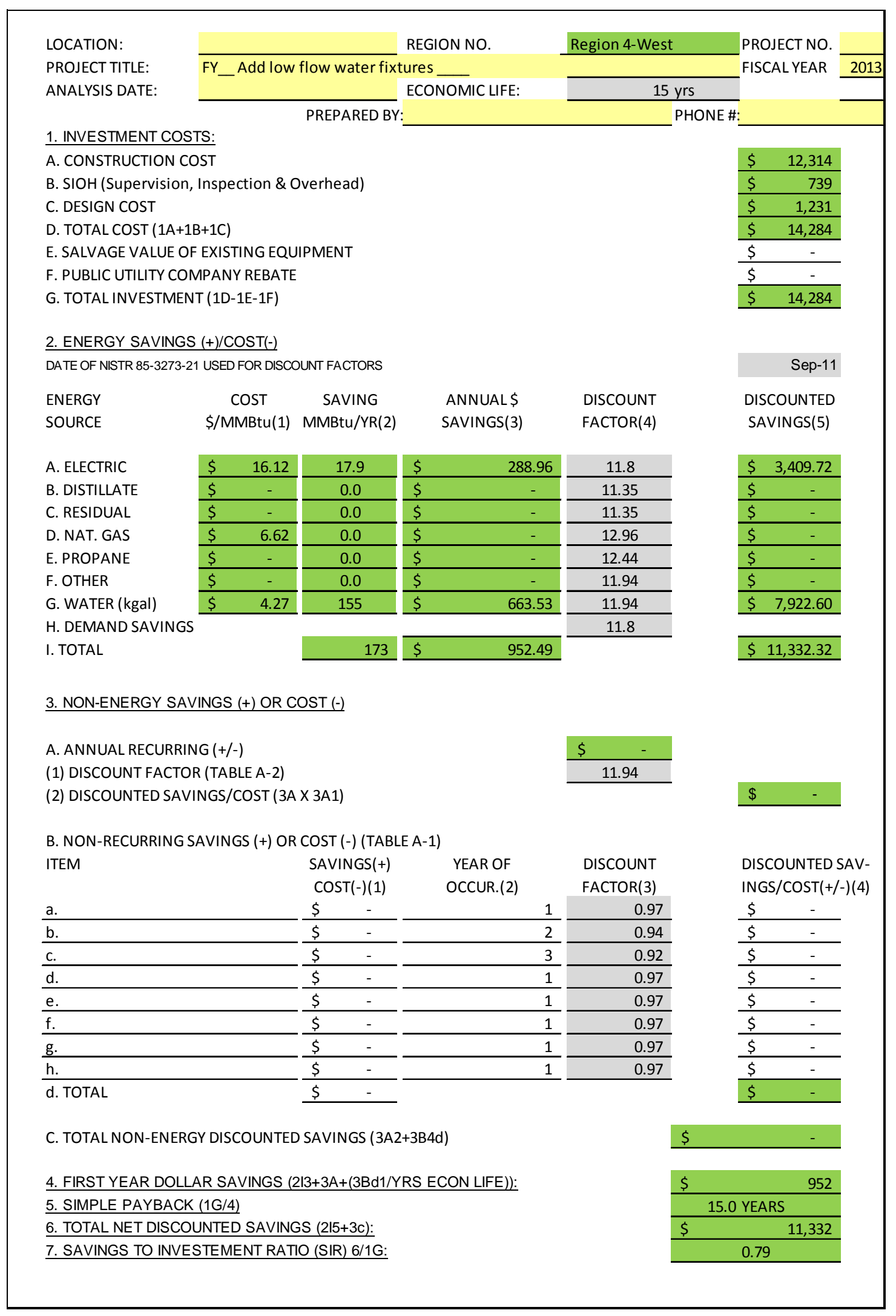




\section{Appendix E}

\section{Assumptions for Second Floor Vestibule}

The following assumptions were used to estimate the savings associated with a vestibule for the second floor office area. The assumptions also take into account that the building engineer measured the flow through the door which resulted in slightly lower and highly variable flows thru the door opening which was timed at 10 seconds from the initial opening to complete closure. In addition, because RPL has radiological and chemical hazards in the facility, the flow from the exhaust fans is considerably higher than the flow from the supply fans; causing a funneling effect when the door is open. This effect was deliberately not taken into account in the calculation to generate a conservative savings estimate.

Assumptions/Equations:

- Vestibule Required: Small $<150$ square feet (estimated)

- Annual average wind speed (Richland, WA ) ${ }^{1}=22 \mathrm{mph}$

- $\quad$ Number of occupants on second floor = 59 (Map Tool); conservatively assumed approximately half of the occupants use the door and average of 2 openings per occupant per day

- Average effective time door open= 6 seconds

- Door Size: 32 square feet

- Office hours: 40 hours per week,5 days per week,50 weeks per year

- $100 \%$ electrical heat

- Cooled by: air-cooled reciprocating chillers (closest to actual central air plant/screw chiller)

- Degree days based on Richland, Washington per National Climatic Data Center NCDC 19812010 Monthly Normals

- The SIOH (Supervision, Inspection and Overhead) and design costs were increased because RPL is a unique facility with radiological and chemical hazards requiring additional safety oversight.

Calculated air volumes through an open door using assumptions above as:

- Air volume thru an open door (cfm):

22 miles/hour*5280 feet/mile*(1hour/60 min)*32 square feet $=61,952 \mathrm{cfm}$

Frequency $(\mathrm{F})$ of an open door - using the assumptions above: $\mathrm{F}=30$ occupants/day*2 openings/occupant*6 sec/opening/(3600 sec/hour)* 5 days/week=0. 5 hr. /wk.

Fuel consumption $(E)=1.08 * c f m * D D * 24 *(F) / 40 ~ h r / w e e k) * /(H * E F F)$;

- $\quad$ where $\mathrm{cfm}$ = cubic feet per minute of open door, as calculated above,

- where DD = degree days, annual heating/cooling

- where $\mathrm{F}$ = frequency of open door, as calculated above

- where $\mathrm{H}$ = conversion for fuel, as desired

- $\quad$ where EFF = annual efficiency of heating/cooling equipment

\footnotetext{
${ }^{1}$ http://www.usa.com/richland-wa-weather.htm\#HistoricalWind Speed
} 


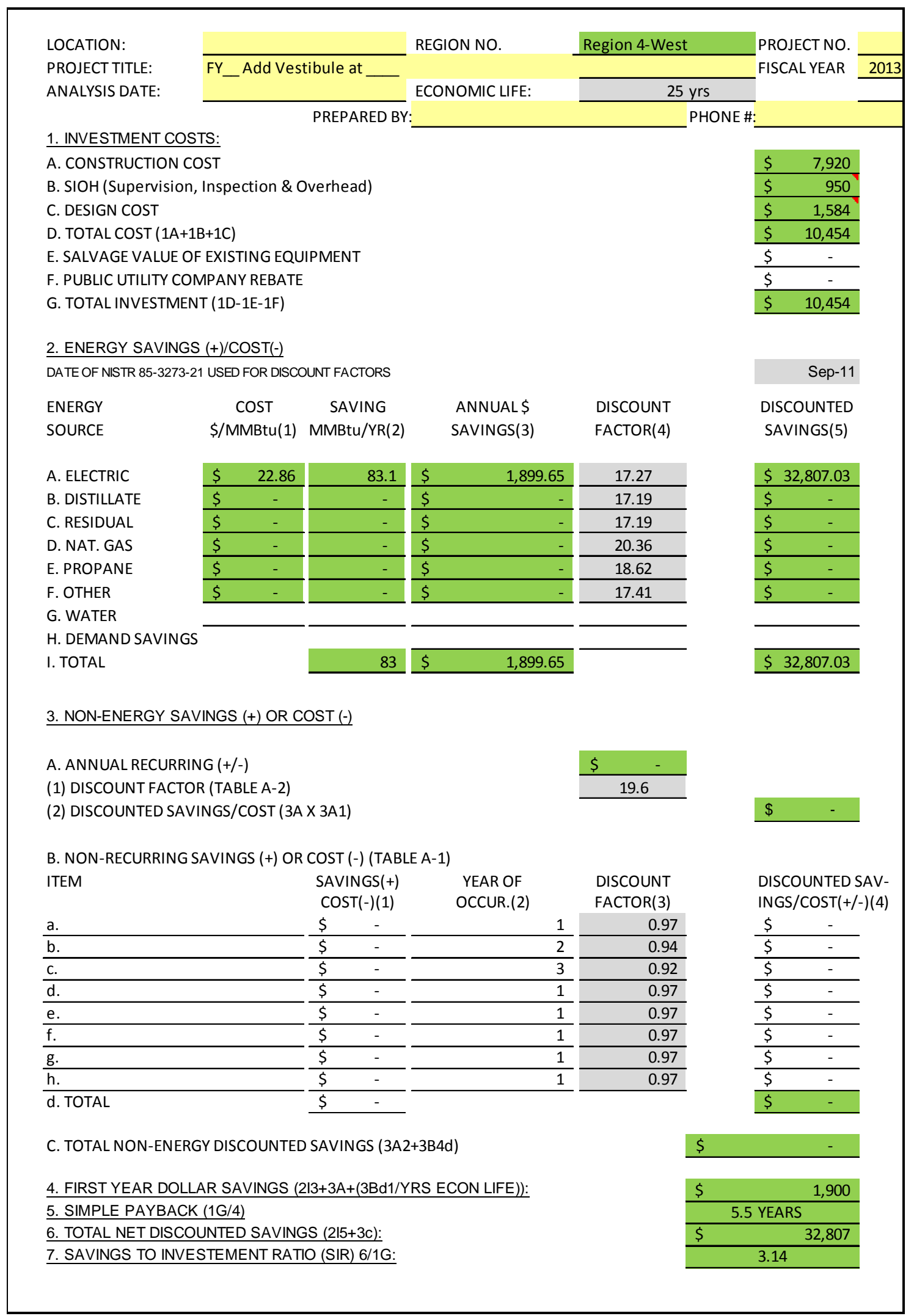


Appendix $\mathrm{F}$

Motor Master+ International Outputs 


\section{Appendix F}

\section{Motor Master+ International Outputs}

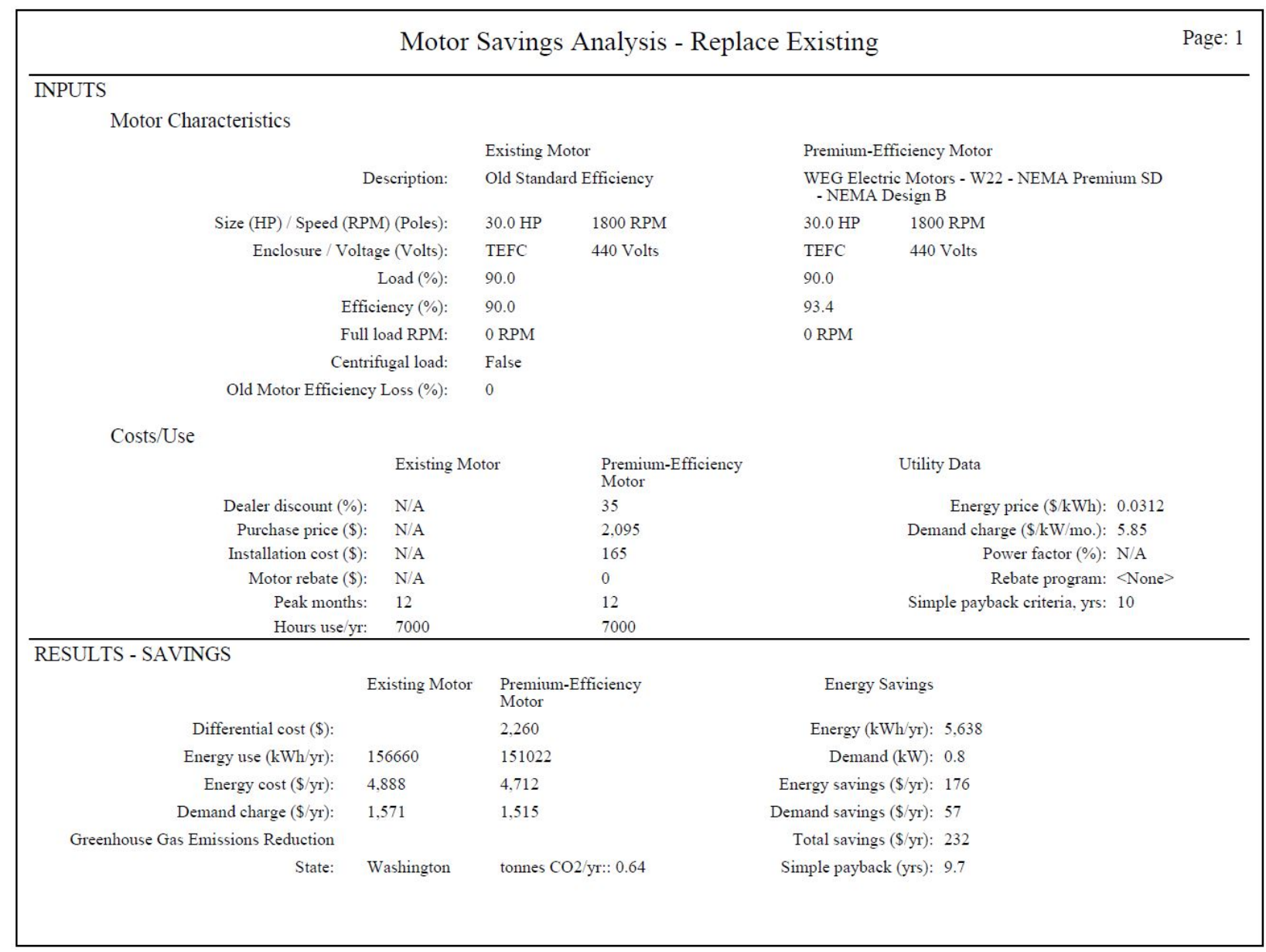

30-hp US Motor used for Pre-Heat Pumps and Heat Recovery Pumps 


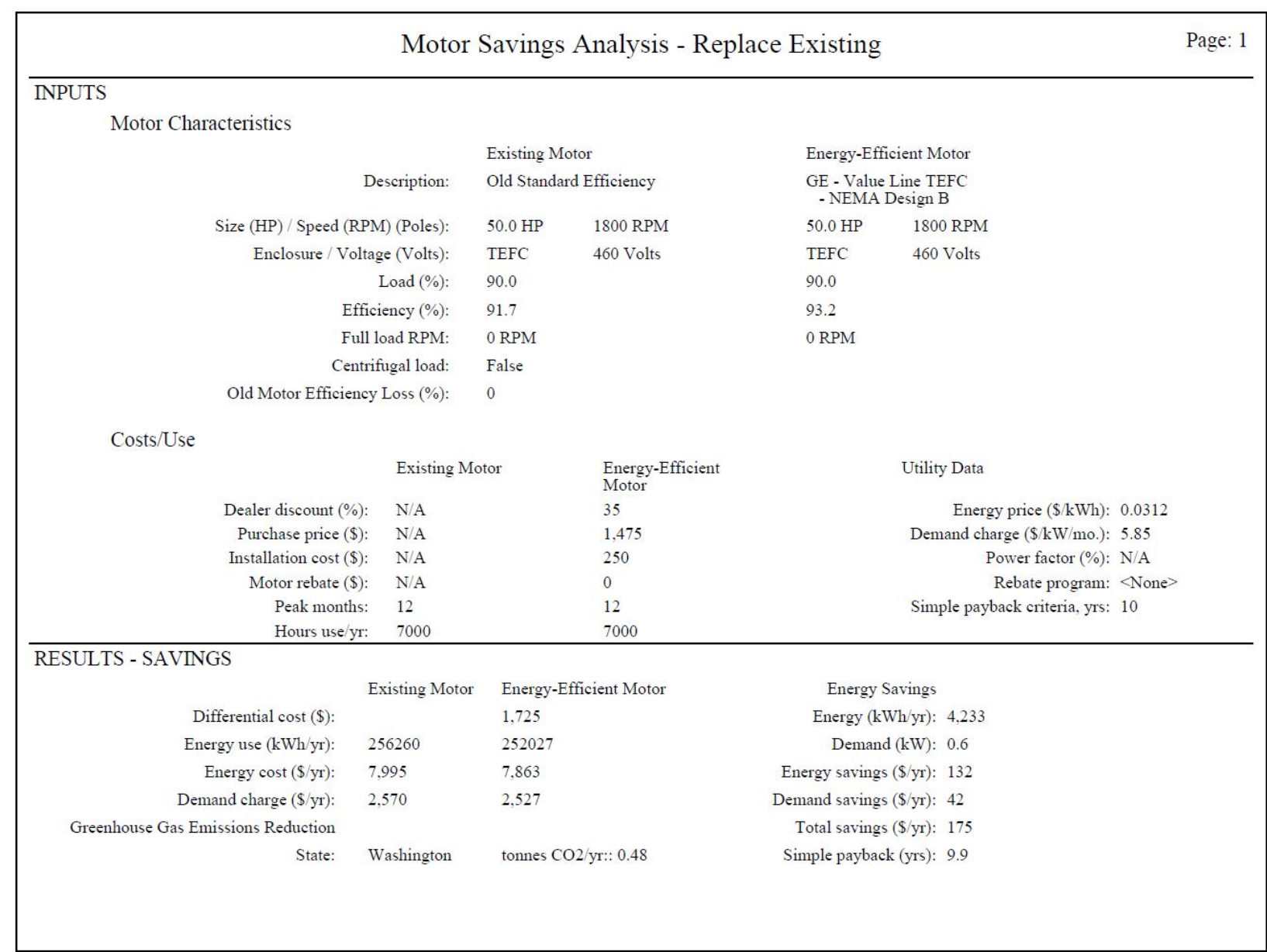

50-hp Lincguard Motor used for Pre-Heat Pumps and Re-Heat Pumps 


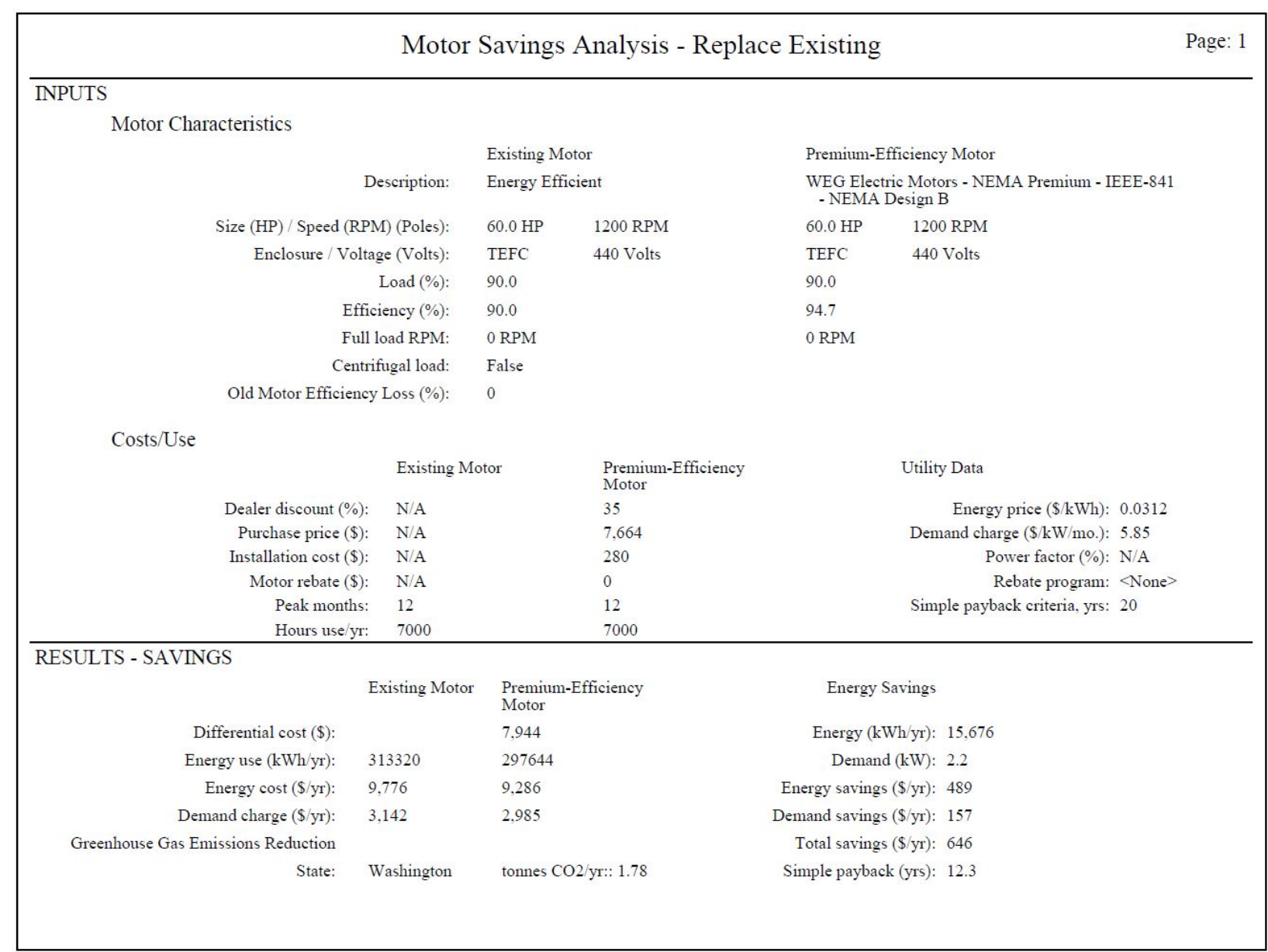

60-hp Westinghouse Motor for the Main Supply Fans 


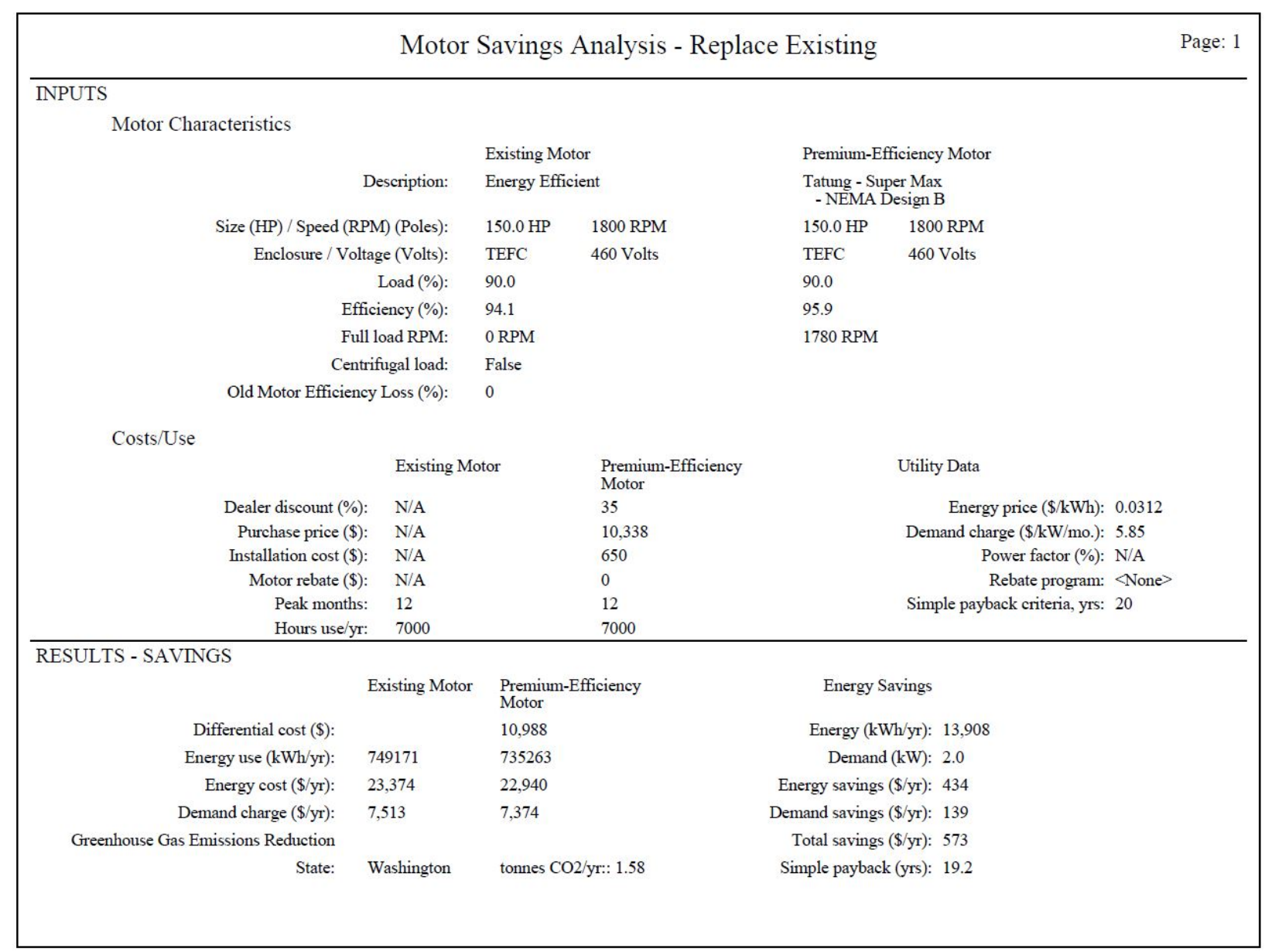

150-hp Lincguard Motor for the Main Exhaust Fans 



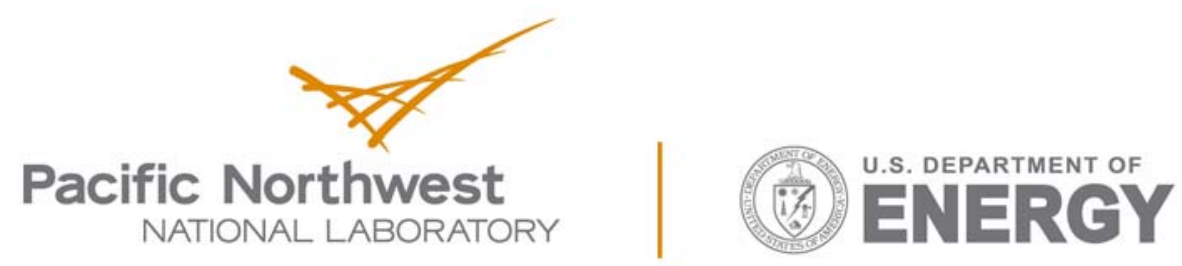

Proudly Operated by Battelle Since 1965

902 Battelle Boulevard

P.O. Box 999

Richland, WA 99352

1-888-375-PNNL (7665)

www.pnnl.gov 